\title{
System and market integration of wind power in Denmark
}

Lund, Henrik; Hvelplund, Frede; Alberg Østergaard, Poul; Möller, Bernd; Vad Mathiesen, Brian; Karnøe, Peter; Andersen, Anders N.; Morthorst, Poul Erik; Karlsson, Kenneth Bernard; Münster, Marie Total number of authors:

12

Published in:

Energy Strategy Reviews

Link to article, DOI:

10.1016/j.esr.2012.12.003

Publication date:

2013

Document Version

Peer reviewed version

Link back to DTU Orbit

Citation (APA):

Lund, H., Hvelplund, F., Alberg Østergaard, P., Möller, B., Vad Mathiesen, B., Karnøe, P., Andersen, A. N., Morthorst, P. E., Karlsson, K. B., Münster, M., Munksgaard, J., \& Wenzel, H. (2013). System and market integration of wind power in Denmark. Energy Strategy Reviews, 1, 143-156.

https://doi.org/10.1016/j.esr.2012.12.003

\section{General rights}

Copyright and moral rights for the publications made accessible in the public portal are retained by the authors and/or other copyright owners and it is a condition of accessing publications that users recognise and abide by the legal requirements associated with these rights.

- Users may download and print one copy of any publication from the public portal for the purpose of private study or research.

- You may not further distribute the material or use it for any profit-making activity or commercial gain

- You may freely distribute the URL identifying the publication in the public portal 


\title{
System and Market I ntegration of Wind Power in Denmark
}

\author{
Henrik Lund, Frede Hvelplund, Poul Alberg Østergaard ${ }^{1}$, Bernd Möller, Brian Vad Mathiesen, \\ Peter Karnøe Department of Development and Planning, Aalborg University, Aalborg, Denmark
}

\author{
Anders N. Andersen \\ EMD International, NOVI Research Park, Aalborg, Denmark \\ Poul Erik Morthorst, Kenneth Karlsson and Marie Münster \\ Technical University of Denmark, Management Engineering, Risø Campus, Roskilde, Denmark \\ Jesper Munksgaard \\ Copenhagen Energy, Copenhagen, Denmark \\ Henrik Wenzel \\ Institute of Chemical Engineering, University of Southern Denmark, Odense, Denmark
}

Publication info:

Energy Strategy Reviews, Volume 1, Issue 3, March 2013, Pages 143-156,

http://dx.doi.org/10.1016/j.esr.2012.12.003

\begin{abstract}
Denmark has more than 10 years of experience with a wind share of approximately 20 per cent. During these 10 years, electricity markets have been subject to developments with a key focus on integrating wind power as well as trading electricity with neighbouring countries. This article introduces a methodology to analyse and understand the current market integration of wind power and concludes that the majority of Danish wind power in the period 2004-2008 was used to meet the domestic demand. Based on a physical analysis, at least 63 per cent of Danish wind power was used domestically in 2008. To analyse the remaining 37 per cent, we must apply a market model to identify cause-effect relationships. The Danish case does not illustrate any upper limit for wind power integration, as also illustrated by Danish political targets to integrate 50 per cent by 2020. In recent years, Danish wind power has been financed solely by the electricity consumers, while maintaining production prices below the EU average. The net influence from wind power has been as low as 1-3 per cent of the consumer price.
\end{abstract}

Keywords: Wind Power; wind power integration; Wind Power Cost; Energy System Analysis; Electricity Markets;

\section{Introduction}

\footnotetext{
${ }^{1}$ Corresponding author e-mail: poul@plan.aau.dk, phone +45 99408424, Vestre Havnepromenade 9, 9000 Aalborg, Denmark
} 
In many countries and regions, the political wish to combat climate change as well as to secure energy supply and create industrial development and jobs has led to the formulation of long-term objectives of sustainable energy as well as short and mid-term strategies of implementing the first steps. The Danish Parliament has decided on the long-term target of a fossil-free energy system by 2050 and has, in the spring of 2012, agreed on an ambitious plan to implement the first step by 2020, including an increase in the wind power production from around 25 per cent to 50 per cent of the electricity demand.

In neighbouring Germany, a phase-out of nuclear power and a parallel expansion of renewable energy is envisioned to reach a renewable energy share corresponding to 80 per cent of the electricity demand in 2050 [1]. Likewise, in the United Kingdom, ambitions include an 80 per cent reduction in carbon dioxide emissions by 2050 compared to 1990 and, as a stepping stone to this, "power sector emissions need to be largely decarbonised by the 2030s" [2]. Sweden has adopted similar targets and plans to be carbon neutral by 2050 with a short-term objective of 50 per cent renewable energy by 2020 [3].

Such and similar targets have generated significant activity in the research community in the development of theories, tools and methodologies to design, analyse and implement such strategies.

In terms of discussing future systems and the market integration of wind power, such as the smart grid concept, Denmark is an interesting case. Today, the Danish wind power production is equivalent to approx. 25 per cent of the electricity demand, and Denmark has more than 10 years of experience in producing and utilising a wind power input of approximately 20 per cent of the national electricity demand. In some municipalities in the western part of Denmark, the share is even in the order of magnitude of $100 \%$.

During the same 10 years, electricity markets have been subject to developments with a key interest in integrating wind power as well as trading electricity with neighbouring countries.

Frequently, strategies aiming at curbing carbon dioxide emissions combine energy efficiency and conservation with the replacement of fossil fuels by a combination of wind power or similar fluctuating renewable energy sources and biomass. Consequently, the integration of fluctuating power sources into the electricity grid becomes essential and the discussion and development of so-called smart grids have attracted a lot of attention.

Smart grids may be perceived as electricity systems adapted to the requirements of distributed generation based on fluctuating energy sources in the sense that they offer the required flexibility for an adequate system integration of these. Typically, the separation of production and demand is not strong in these systems, thus allowing the bidirectional use of the grid. This issue has been researched for a long period of time in different terms $[4-6][7,8][9,10]$. Elements of this research include flexibility in the production system, flexibility in demand [11][12,13], flexibility by using storage systems [14], impacts on the grid [15-18] and improved integration between energy 
sectors, as deliberated in a series of articles [19-22,22-32]. Holistic energy systems analyses encompassing both technologies with a fluctuating nature and technologies adding flexibility [33-35] [36-41] also present work which may effectively be labelled smart grids, but as argued more explicitly in [42], there is a need for a transition to smart energy systems, not just smart grids, and framework conditions including market constructs need to adapt to the needs of more flexible systems [43]. In terms of wind power integration, the referenced work addresses many of the technical challenges associated with large-scale wind power integration.

The fact that Denmark has exchanged significant amounts of electricity on the Nordic electricity market as well as with Germany during some years has led some observers to conclude that Denmark does not utilise the wind but exports it instead. On this basis, it is claimed that other countries cannot copy the Danish example.

Moreover, the fact that private household consumers pay a high electricity tax has led observers to claim that Danish wind power is extremely expensive and that wind power is a large burden on Danish taxpayers.

While we agree that there are significant challenges associated with transforming the Danish and any other energy system based on centralised power plants to accommodate high shares of wind power, our analysis contradicts the claims that this transformation leads to higher taxes, more discarded electricity, and low-priced export. The circulation of such wrong claims makes the public debate and policy making about these complex issues even more difficult. For methodological clarity, this article presents a particular Danish case of such a circulation of wrong claims and misunderstandings. The chosen case study contains all the elements mentioned above. The study which we present and against which we argue is "Wind energy - The case of Denmark" from September 2009 [44], produced and published by the Danish think tank CEPOS. The study claims 1) that most of the Danish wind power has been exported in recent years, and 2) that wind turbines in Denmark are very costly to Danish taxpayers and electricity consumers.

The study states that wind power "has recently (2006) met as little as 5\% of Denmark's annual electricity consumption with an average over the last five years of 9.7\%". Later, the same study states that "a significant fraction of the charges and taxes paid for by Danish domestic consumers is recycled to support [..] the feed-in tariffs that make it attractive [..] to invest in wind power".

Based on a graphical pattern, Sharman makes a similar interpretation of Danish wind power: "west Denmark makes full use of its interconnections for balancing wind power as there is a strong correlation between wind output and net power outflows" [45]. Ferguson points to efficiency loss in operating thermal power plants: "No one knows exactly just how much less efficiently a plant actually operates when it has to run in harness with wind turbines, however the effect is not small", and, based on other papers by himself [46,47], Ferguson continues to state that "In the extreme case of an allnatural-gas system, it can be shown that the loss of efficiency of the plant operating 'in harness' outweighs the benefit from the wind input". A purportedly questionable effect of wind power and the associated cost represent a recurring theme in the Optimum Population Trust Journal, in which the listed papers are published. Through an analogy 
with the lower fuel efficiency of automobiles running intermittently in urban traffic compared to highway traffic, Inhaber [48] points to the same issue of efficiency loss in the case of the thermal power generation plants.

Evidently, both issues are essential to the understanding of the challenges related to the future integration of wind power. Therefore, this article presents and applies a methodology to analyse to which extent the historical Danish energy system has been able to make use of the Danish wind power production domestically and applies the methodology to the year of 2008. Based on the results, it is discussed how to design the future system to adapt to the plans of a further increase in wind power input. Moreover, this article analyses the influence of the same wind power input on electricity consumer prices in the period 2004-2008.

\section{Danish Wind Power and Export}

From 2000 to 2010, Danish wind turbines generated in a normal year the equivalent of approx. 20 per cent of the Danish electricity demand. In 2008, the figure was 19.3 per cent.

The question is if one can determine to which extent the wind power has been exported or used to meet domestic demands.

This is not a simple calculation, since the load balancing of an electricity system requires access to balancing and regulating reserves in order to make the system function, and, in such regard, Denmark is well-connected to neighbouring countries through transmission lines.

Denmark is part of the European Network of Transmission System Operators for Electricity (ENTSO-E) [49]; an international collaboration in which a large number of European countries assist one another in securing the balancing task, e.g. within the supply of primary automatic reserves. Thus, Denmark draws upon the assistance of other countries and helps them in return. That includes the balancing of wind power in Denmark as well as in Denmark's neighbouring countries. One of these countries is Germany, and the northernmost state of Germany, Schleswig-Holstein, has an installed wind power capacity similar to that of Denmark.

When wind capacity in Denmark increases, the system may need more regulating power due to the fluctuating nature of wind power. Historically, and starting before the wind power era, Denmark has shared a well-functioning regulating power market with Finland, Norway and Sweden, which has the necessary capacity to provide all the upand downward regulating power needed in order to operate the system. It is most costeffective to handle the regulation in the Nordic power system via a common regulating power market, analogous to the distribution of primary (frequency) reserves among countries. Danish regulating power resources are used whenever it is most costeffective, given the particular mix of energy production technologies in the system and the corresponding market prices at any point in time. Moreover, all the costs of operating this regulating power market are included in the electricity price. As 
regulation based on Norwegian or Swedish hydro power with storage capacity is often more cost-effective than local Danish regulating resources, the hydro power will be prioritised in the merit order. Given the present institutional set-up, this solution is working well for all countries involved, but it does not reflect the ability of the Danish system to regulate solely by the use of local resources; i.e., the ability to regulate power resources and load balancing by using local-regional resources. This issue is addressed later in this article.

Data on power production and export from the present technology mix in the Danish energy system is illustrated here for the year 2008. In 2008, wind turbines in Denmark produced 6,978 GWh (Based on data from [50]), corresponding to 19.3 per cent of the electricity demand (36,105 GWh) (Based on data from [51]).

During a few hours, the wind power production exceeded the total demand and the excess production was naturally exported. However, analyses of the hourly data from [50] shows that this happened during a total of only 43 hours in 2008, and the total excess production exported in such periods was as low as $5 \mathrm{GWh}$, equal to less than 0.1 per cent of the wind power production (or less than 0.02 per cent of the demand).

During other hours, there was either no export at all or the wind power production exceeded the export. During such hours, the share of wind power produced which exceeded the export would have to be used domestically - no other outlet for this wind power exists. The sum of wind power produced in periods with no export and the wind power exceeding the export, therefore, must have been used domestically. In 2008, this domestically used production was as high as 4,398 GWh equal to 63 per cent of the wind power production (or approx. 12 per cent of the demand). It should be noted that this figure only includes the share that exceeds the export.

Consequently, one can say, for a fact, that a minimum of 0.1 per cent of the Danish wind power production in 2008 was exported and a minimum of 63 per cent was used in Denmark.

With regard to identifying any export related to the remaining 36.9 per cent, two different methodologies will be discussed in the following: The statistical hourly correlation approach versus the market understanding causal relation-based approach.

\subsection{The statistical hourly correlation approach}

The statistical hourly correlation approach was used in [44], leading to the conclusion that wind power "has recently (2006) met as little as 5\% of Denmark's annual electricity consumption with an average over the last five years of $9.7 \%$ ”.

The approach followed in [44] has in this article been replicated by using the same data as in said study, namely hourly electricity data from the Danish TSO Energinet.dk [50]. These hourly data include consumption and production divided into 1) wind power, 2) large power plants (extraction and condensing mode plants) and 3) small CHP plants in the two separate supply areas of Denmark, i.e. west and east, from January $1^{\text {st }} 2000$ until present. 
If one presumes that all export by default is wind power (until the export exceeds the wind power production), one can replicate the mentioned 5 per cent of 2006. This, however, would be a worst-case assumption but it appears to be the assumption forming the ground for the calculations in [44]. For the most recent year, 2008, the figure will be 12 per cent, based on the same assumption. However, if one assumes that all export by default is large and small power stations rather than wind power, the figure would be 17 per cent in 2006, practically equal to the total wind power production of that year. Under this assumption, the export of wind power would be as little as 0.01 per cent of the demand. The same pattern shows for 2008.

Consequently, the 5 per cent claim must originate from the assumption that all export by default is wind power, and as the figures show, the choice of assumption bears a large impact on the assessment of wind power's coverage of Denmark's electricity demand. The main argument for making this assumption is that the Danish export of electricity is generally higher during hours of high wind production than during hours of low wind production. Using such assumptions, [44] shows diagrams which illustrate such an apparent correlation for Western Denmark 2007 and Eastern Denmark 2006 and concludes: ".. the coincidence of so much wind output with net outflows makes the case for claiming that there is a large component of wind energy in the outflow, indisputable”. Based on this argument, it could wrongly be implicitly assumed that all export by default is wind power (until the export exceeds the wind power production) so the authors of this article dispute this assertion.

Fig. 1 shows a dot plot of wind power versus export for Western Denmark in 2008, and the tendency appears to be that the higher the wind power production, the higher the export.

However, Fig. 2 demonstrates that this is not unique to wind power. This is general to all types of production units in the Danish electricity system. Conducting the same analysis of the large CHP (combined heat and power) and power plants gives the result illustrated in Fig. 2. As one can see, there is no real difference between the plot of wind power versus export and the plot of large CHP and power plants versus export; they have the same degree of correlation, which, by the way, is not a strong statistical correlation. Accordingly, one could use more or less the same argument for large power plants as for wind power. In both cases, however, the argument would be wrong. As will be shown, the causal relation behind export is more complex and involves the understanding of the market mechanisms and cost implications of the various power suppliers on the Nordic power grid.

Figs. 3-5 show similar diagrams for all production units in the Danish system divided into 1) wind turbines, 2) large power plants and 3) small CHP plants including statistical correlations. The three diagrams show a tendency towards high export more frequently taking place during hours of high wind production than during hours of low wind production. However, the same is the case of the production on both large and small CHP plants. For wind power, the correlation coefficient $\mathrm{R}$ is as low as 0.62 and $\mathrm{R}^{2}$ is only 0.39. Such a correlation is quite poor and cannot justify any conclusion about a causal relation. Therefore, none of these diagrams indicate the causal relation, i.e., 
which units cause the export. It is not possible, based on any of these diagrams, to conclude that all export by default is wind power. Nor is it possible to conclude that all export comes from any of the other units.

In order to identify any causal relation, it has also been analysed if changes in export from one hour to another derive from wind power more than from other production units. Such an analysis has been made by calculating all hourly changes in 2008 in export and wind power production and plotting these into a diagram, as shown in Figs. 6 and 7. In Fig. 6, all dots in the upper right-hand quadrant represent hourly changes where both wind power and export increase relative to the previous hour. Similar dots in the lower left-hand quadrant represent hourly changes where they both decrease. Thus, all dots in these two quadrants represent a correlation between hourly changes in wind and changes in export. However, in the other two quadrants, the opposite takes place. In this case, export decreases as wind power increases and vice versa. If the presumption that all changes in export derive from wind power was true, one would expect all dots to be on the red line. However, as one can see, this is far from the case.

In Table 1, we have identified the number of dots in each of the four quadrants. As illustrated by the table, the analysis shows that there is no strong correlation between hourly changes in wind power and export. There is a high-high and low-low coincidence in approx. 60 per cent of the hours. However, in the remaining 40 per cent, wind power decreases when export increases or vice versa. Such correlation is not unique to wind power. The same is the case with regard to large power stations. Looking at the energy ( $\mathrm{GWh}$ ) rather than the number of hours does not change the picture.

The two correlation coefficients (R) are calculated and shown in Figs. 6 and 7. Normally, one would require an $\mathrm{R}^{2}$ of around 0.9 or above to indicate a strong correlation. As one can see, the correlation between changes in wind power and import/export is as low as $\mathrm{R}=0.30\left(\mathrm{R}^{2}=0.0872\right)$, while the correlation between changes in large power plants and import/export is $R=0.65\left(R^{2}=0.4269\right)$. Consequently, such an analysis does not in any way suggest that changes in import/export are generated by changes in wind power. On the contrary, it points to the fact that such changes may be generated by changes in the production at large power stations. As elaborated on later, the causal relations are more complex and involve market mechanisms and cascading effects between power suppliers; i.e., wind power releases capacity for export at e.g. large CHP plants. These are, in turn, competitive with e.g. German and Finnish power plants, thus leading to an export of electricity from large CHP plants in situations with high wind production. Hence, high wind production leads to the replacement of foreign fossil-based power production by Danish fossil-based power production. This replacement is due to market mechanisms, and not due to wind power being exported.

Consequently, none of the diagrams in Figs. 1-5 showing apparent correlations over time can be used to establish a causal relation between wind power and export. On the contrary, they indicate that wind power in general does not influence export any differently than other production units. 
Moreover, as a general comment, the use of hourly statistics to try to determine the impact of wind power on other production units inherently gives a faulty time perspective. Due to the impact of hydro power with storage capacity, it is necessary to look at longer time spans if one wishes to determine which plants have been affected by the wind power produced. Another approach can be to look at marginal costs, as elaborated on below.

To establish a causal relation, one has to examine why the Danish energy system ends up exporting or importing electricity. Such causal relation has to do with the functionality of international (Nordic) electricity markets and how the independent power generators respond to price incentives. Most export is generated in power plants for the simple reason that it is financially attractive for the Danish power producers to generate power and sell it on the international power market. Such export is highly influenced by the fact that Denmark has a significant share of CHP which makes fossilbased power plants competitive with foreign power plants, mainly due to the economic advantage of district heating and the consequential lower marginal production cost of power.

The following two examples illustrate why the causal relation can only be established by observing the electricity markets.

Fig. 8 compares two different hours of production in 2008: one hour in January with significant export and one in March with no export. In both situations, the production from wind turbines is approx. $1000 \mathrm{MW}$ and the total Danish consumption is around $3200 \mathrm{MW}$. The large difference shows in the production of the large CHP and power stations. On March $10^{\text {th }}$, the production of these was approx. $1000 \mathrm{MW}$, while on January $5^{\text {th }}$, the production was more than 1900 MW. Moreover, the production of the small distributed CHP plants was a little higher in March than in January.

It is obvious that the production of wind power in this situation can hardly explain why Denmark chose to export in January and not in March.

Nevertheless, using the simplistic correlation assumption in [44] would lead to the erroneous claim that all export in the January case is based on wind power, while all electricity produced by the power plants is used in Denmark.

Decomposing the contributions of the different generators in Fig. 8, it is clear that large power stations generated much more electricity in the January case than in the March case while in both cases, wind power production was about $1000 \mathrm{MW}$ as mentioned. However, one significant difference between the two hours is the price on the Nord Pool international electricity market, which was only 234 DKK/MWh on March $10^{\text {th }}$ and substantially higher on January $5^{\text {th }}$, namely $386 \mathrm{DKK} / \mathrm{MWh}$. Consequently, the power stations may make a profit by exporting in January but not in March. This suggests that the market price may play an important role to the production level of power stations.

Fig. 9 is even clearer on the alleged causality between electricity production from wind turbines and export. As one may observe in Fig 9, there was no export during hours 1 to 11 and after 13, but a little export between the hours 11 and 13 on June $14^{\text {th }}$, 2008. Such 
exports can by no means be claimed to be from wind turbines by default. Fig. 9 shows that there is no evidence to support such an interpretation.

The coal-fired large CHP and condensing mode plants in Fig 9 increase their production in the same period and the system ends up exporting. However, if the large plants had not increased their production, there would be no export. The reason for the production increase during such hours is likely to be the economic appeal of doing so; i.e. the income from the Nord Pool electricity market exceeds the marginal production costs. The fact that this is a summer scenario makes it even clearer, as changes in electricity production are not likely to be caused by the need to produce additional heat on the CHP units.

Looking at the exact Nord Pool price of that day, it shows an increase during exactly the same hours as when the large power plants increase production and peaks between 11 and 13 o'clock. Consequently, with the current price mechanism on the Nord Pool market, it is economically rational for the power producers to increase production, and the aggregated effect of the increased production is the export of electricity from the 'system'.

The point is that even though there is a weak correlation over time between wind power and export, this does not establish a causal relation. The reasons for exporting have to be found by observing the market mechanisms of international electricity markets and, as we shall see, such an observation shows a causal relation between market price and the production at large power plants, but hardly any causal relation between export and wind power.

\subsection{A causal relation approach based on market understanding}

With regard to the remaining 36.9 per cent wind power produced, as mentioned in Section 2, one cannot conclude anything from a purely technical, physical or statistical point of view, as deliberated in Section 2.1. During all the remaining hours, the production was a combination of wind power and electricity production from largescale CHP and power plants and small distributed CHP plants, and it is not possible from a technical, physical or statistical point of view to determine which parts of this production were exported and which were used domestically. Such a question cannot be answered solely by looking at the correlation over time.

If one should identify whether export during such hours came from one type of production or another, one would have to establish a causal relation; i.e., explain why and from which units export is generated. Such a causal relation can be established by observing the international electricity markets on which import and export are determined.

Denmark is part of the Nordic electricity market Nord Pool on which the electricity production, demand and price are found as illustrated in Fig. 10. Wind power and other categories of electricity generation are offered at the short-term marginal cost of producing electricity on the given unit. For wind turbines, this is close to zero, whereas power plants with a fuel use have substantially higher marginal costs. This creates a 
notable implication for the power market. By shifting the supply curve to the right, wind power in fact typically reduces the spot market price during a given hour. This is to the benefit of consumers but at the expense of the power units with higher marginal production costs as a result.

Fig. 11 shows the merit order of marginal production on the Nordic Nord Pool Market. Wind power has the lowest short-term marginal production costs in the Nordic power system.

Danish export is possible because Denmark is well-connected with neighbouring countries [18,52] and has access to the international market, as illustrated in Fig. 12. Export takes place when the price outside Denmark is higher than the short-term marginal production costs of the Danish units that are in a position to increase production. In the Danish case, these production costs are influenced by CHP production, as these plants often have the highest operation costs of the plants supplying to the Danish part of the grid.

How export is then generated can be explained by observing the example shown in Tables 2 and 3. In Table 2, there are no interconnectors and hence no export. In such a case, the production in price area 1 (e.g. Western Denmark) will be 2,000 MWh and the price will be 200 DKK/MWh. Production and price in price area 2 (e.g. Southern Norway) will be uncorrelated with production and price in area 1. However, in Table 3, there are interconnectors and thus possible import/export. In this case, the market will settle in a situation in which final prices of $350 \mathrm{DKK} / \mathrm{MWh}$ in Price area 2 and 275 DKK/MWh in Price area 1 are established. Thus, it will pay for power plants 2 and 3 to start producing, so that price area 1 can export to price area 2.

This example clearly illustrates the market principle that the last unit of production entering the market is the unit with the highest bidding price, i.e., the unit with the highest marginal production costs.

The market price on the Nordic grid often drops to a level at which the Danish CHP plants have the highest operation costs of the plants supplying the grid, i.e., condensing mode power plants without district heating exit the market in such hours. When this happens simultaneously with high wind power production, the Danish system often ends up exporting, while the condensing mode power plants, being located in neighbouring countries, are the ones exiting.

Understanding this market perspective and the structure, type and capacities of power suppliers to the Nordic grid, it becomes evident that it is the whole system setting of:

1. high wind power production in Denmark

2. competitive Danish CHP plants with relatively low costs of operation due to the supplementing income of district heating, and

3. the presence of less competitive condensing mode power plants in neighbouring countries

which leads to the sale and export of electricity from the Danish electricity system in high wind periods, while the power plants temporarily ceasing to produce are located in 
other countries. The focus on partial statistical correlations only and the assumption that the exported power is by definition wind power lack all acknowledgement of this understanding.

This acknowledgement is essential to the further interpretation of the potential for wind power integration. Through an understanding of these mechanisms, it becomes clear that the electricity export can only be explained in the systems perspective. Important aspects of the interpretation are:

- if there had been no CHP but only condensing mode power plants in Denmark in 2008, there would probably have been close to no export.

- in other countries with no or low CHP, the least competitive plants would more likely be located within the country, and high-wind periods would thus lead to the curtailment of such plants and not to export,

- if Denmark (or other countries) aim for more regulating power plants or ways to store or convert electricity, there is plenty of space for more wind power,

- the 'Danish case' of 20-25 per cent wind power production compared to electricity demand is in no way an illustration of a scenario in which the limits for wind power integration have been reached.

In reference to this analysis, the technical need for power plant production is expressed in terms of two requirements. It is emphasised that the requirements for the operation of the electricity system are both complex and under constant development, so the requirements presented here serve as illustrative examples:

- Currently, the large power units in the energy system cannot go below a certain technical minimum. In 2008, there were hours during which the large units in Western Denmark were operated at only 415 MW and, in Eastern Denmark, only 181 MW. Consequently, it could be argued that the system can technically be operated with such minimum production and that every production above this level is due to economic and market-based optimisation.

- The grid requires a certain minimum ratio between power production on large central plants and wind power in order to ensure frequency and voltage stability through active and reactive power regulation as well as to have sufficient shortcircuit power available. These so-called ancillary services [23,53] have traditionally been supplied by large power plants with synchronous generators whereas wind turbines with asynchronous generators and sensitive tripping mechanisms have been unable to supply ancillary services. Power plants based on synchronous generators have therefore needed a certain share of the monetary production to ensure a stable grid, although as wind turbines become technologically more advanced, they too can assist the grid [54]. In 2008, hours can be found during which the grids were operated, for Western and Eastern Denmark respectively, with a wind power production of 3.53 and 3.03 times the production of the large power units. Consequently, it can be argued that the system can operate with such minimum shares of production on the large units, meaning that they can reduce the production to this level without compromising the system stability, given the present system configuration. 
By applying the above principles, one can identify hours during which the sum of a) wind power and $b$ ) production on large units of 1/3.53 of the wind power, though never less than $415 \mathrm{MW}$, exceeds the demand. Such excess production can then be defined as wind power being exported, while the rest is export due to a decision to increase the production on the power plants for financial reasons.

By using such principles, the wind power export in 2008 was $61 \mathrm{GWh}$ - equal to less than 1 per cent of the wind power produced (or less than 0.2 per cent of the demand).

However, one modification should be mentioned. In some cases, the marginal production costs of large CHP plants in Denmark are very low and can even be negative, if saved start-up costs are included. However, in the present system, such hours are rare and the export of the wind power produced is with high certainty not much more than 1 per cent in this approach.

\section{The Financing of Danish Wind Power}

As stated in Section 1, the fact that private household consumers pay a high electricity tax has led observers to claim that Danish wind power is extremely expensive and that wind power is a large burden to Danish taxpayers.

\subsection{A misconception about Danish wind power financing}

In order to illustrate common misunderstandings of the Danish wind power financing, we return to the study also referred to previously [44] as a case of these misunderstandings. This study shows bar charts reproduced here as Figs. 13 and 14, including arrows indicating the electricity prices in Denmark for households and industry. We have added the two horizontal, red dashed lines showing the Danish electricity production costs exclusive of taxes and VAT. As one can see, the Danish electricity production costs are at the level of the EU 27 average or below. For example, the Danish electricity prices for industry (exclusive of taxes and VAT) are the $7^{\text {th }}$ lowest out of 27 EU member countries.

Based on Figs. 13 and 14, [44] concludes:

"Taxes and charges on electricity for Danish household consumers make its household consumed electricity by far the most expensive in the European Union (EU). In contrast and in order to keep Danish Industry competitive, power to industry is hardly taxed at all. So the disparity between what householders and industry pay for their power is very wide. As the foregoing charts show, Danish householders pay 2.5 times more than Danish industry. Not all the difference goes to general expenditure.

A significant fraction of the charges and taxes paid for electricity by Danish domestic consumers is recycled to support new energy research and the feed-in tariffs that make it attractive for Danish individuals and companies to invest in wind power. The feed-in support-for-wind-turbines tariff has been the key feature of the Danish wind power expansion from the beginning." 
As illustrated by this quote, this analysis claims [44] that the difference between private and industrial consumer prices in terms of taxes can be partly explained by feed-in support to wind power. These descriptions and conclusions are not correct. They involve two basic mistakes:

Mistake no. 1: The extra payment for $\mathrm{CO}_{2}$ free energy from wind power is not made by the taxpayers. It is made by the transmission company Energinet.dk, and is therefore contained in the electricity price indicated by the blue pillar in Figs. 13 and 14. Taxes and VAT (the upper green and purple elements of the price pillar) are general taxes and have nothing to do with the cost of wind power.

Mistake no. 2: The extra payment for $\mathrm{CO}_{2}$ free energy from wind power is made not only by household consumers, but also by all other consumers, including industrial consumers. This payment is included in the blue element of the price pillar. Thus, the cost of wind power has nothing to do with the difference between the prices for private and industrial consumers.

\subsection{Danish wind power financing}

If the two mistakes from section 3.1 are removed, the horizontal, red dashed line shows the price including the payment for $\mathrm{CO}_{2}$ free wind energy production in comparison with electricity prices in other EU countries. The following can be concluded:

a. The price of electricity production and distribution for household consumers including payment for 20 per cent wind power is the $10^{\text {th }}$ highest out of the 27 EU countries. Furthermore, the Danish electricity prices for households, including payment for wind power but excluding general taxes, are below the average among the old EU member states, EU 15.

b. The price of electricity production and distribution for industrial consumers including payment for wind power is the $7^{\text {th }}$ lowest out of the $27 \mathrm{EU}$ countries, and much below the average of both EU 27 and EU 15.

On this basis, we can conclude that Danish electricity prices, including the extra payment for $\mathrm{CO}_{2}$ free wind power, are still below the average in EU 27.

Table 4 shows a comparison of industrial electricity prices and the share of renewable energy sources for 19 out of the $27 \mathrm{EU}$ countries in which the industrial electricity price is higher than the Danish electricity price for industrial consumers including payment for wind power. Such comparison shows that, for instance, the UK has industrial prices that are 18 per cent higher than the Danish electricity prices for industrial consumers, despite the fact that the UK uses only 5 per cent renewable energy and 3 per cent wind power. Out of the 20 countries with the highest industrial electricity prices, Denmark has the lowest prices for industrial consumers, including the cost of wind power, and the highest share of wind power.

On this basis, we can conclude that Danish electricity prices, including the extra payment for 20 per cent $\mathrm{CO}_{2}$ free wind power, are below the European average and among the lowest of the old EU members, EU 15. A similar conclusion is reached in a recent study [55] which analyses the correlation between the increase in the share of renewable energy and the electricity prices. It shows that the countries with the highest 
increase in renewable energy shares have had a lower increase in electricity prices than countries with a lower increase in renewable energy shares.

Even though the Danish electricity prices including payment for wind power are among the lowest in Europe, wind power still influences consumer prices. However, when looking at wind power's impact on consumer prices, one has to consider two effect areas; namely 1) consumers' payment for wind power, and 2) additional competition created by wind power on the Nord Pool market.

\section{Electricity consumers' payment for wind power-based $\mathrm{CO}_{2}$ free electricity.}

The payment for wind power is handled by the Danish TSO Energinet.dk and is listed in Table 5, which shows consumer payment for wind power-based electricity. Again, it should be noted that this payment is included in the blue bars in Figs. 13 and 14, and is thus paid by the power consumers and not via public taxes.

\section{The effect of wind power on the electricity prices on the Nord Pool power market}

However, consumers' payment for wind power is not the only influence wind power has on consumer prices. Wind power also creates additional competition on the Nord Pool market, which induces a downward price pressure on an oligopolistic market (as already illustrated by the examples in Tables 2 and 3).

Fig. 15 summarises the impact of wind power production on Nord Pool electricity prices. As the figure shows, it is generally found that the consumer prices of power (excluding transmission and distribution tariffs, taxes and VAT) would have been approx. 3-10 per cent higher in Denmark in 2004-2008, if wind power did not contribute to the power production (left part of Fig. 15). The strongest impact of wind power is estimated for Western Denmark due to the high penetration of wind power in this area. In 2007-2008, this adds up to approx. 0.3-0.4 €屯/kWh saved by power consumers due to wind power lowering the electricity prices (right part of Fig. 15).

\section{The net effect of wind power on the electricity prices combining both aspects}

By combining the two above-mentioned aspects, the net effects of wind power are calculated and shown in Table 6 . As the table shows, the influence of direct payment to the wind turbines has in recent years made consumer prices vary between 0.28 and 0.73 $€ \notin / \mathrm{kWh}$ with an average of $0.54 € \notin / \mathrm{kWh}$. However, this is reduced by the lowering effects of wind power on consumer prices varying between 0.10 and $0.38 € \notin / \mathrm{kWh}$. The net price increasing effect (Table 6 Column 4) is at an average of $0.27 € \mathbb{C} / \mathrm{kWh}$, equal to approx. 3 per cent of industrial and 2 per cent of private consumer prices (not including taxes and VAT). If taxes and VAT are included, the net influence of wind power is as low as 1 per cent of the electricity price for household consumers.

Consequently, it is only fair to conclude that the influence of wind power on Danish consumer electricity prices is small and in general negligible.

Moreover, it should be noted that the net influence in 2008 was positive (seen from the consumers' point of view) and actually reduced the consumer prices slightly for both industrial and private consumers. This is interesting, since the analysis in [44], based on 
Figs. 13 and 14, uses the same year to claim the opposite, namely that wind power causes higher electricity prices.

The figures in Table 6 do not take into account the fact that wind power also influences the electricity prices during hours with no wind. The reason is that wind power, during hours with wind, replaces hydro power, which is then saved and put on the market in hours of no wind. This decreases consumer prices. Such an effect is not included in the calculations and would increase the positive influence of wind power even further.

\section{How can more wind power be integrated in the future?}

As described, historically, Denmark has demonstrated how to supply approx. 20 per cent of its electricity demand by wind power. However, the Danish Parliament has decided to increase the share of wind power to 50 per cent by 2020. So what about the future? How will Denmark (and other countries) be able to utilise such high percentage of wind power in a way which makes it possible for neighbouring countries to do the same?

Various studies by researchers from universities, consultancy companies, the Danish TSO Energinet.dk and the Danish Energy Agency have examined how to deal with such a challenge [7,28,56-69]. From these studies, the following results can be highlighted:

1.

Denmark has a high number of small CHP plants producing both heat for district heating and electricity. Most plants were established in the mid/late 1990s and were designed with heat storage capacity to be able to place electricity production at peak hours while still supplying district heating when the electricity consumption is low during nights and weekends. Changing the regulation strategy of Danish small CHP plants to take account of fluctuations in both demand and wind power, instead of only demand, was the first less costly step to help the integration of wind power. Such a step was, for a large part of the small CHP plants, implemented in January 2004, when they shifted from a fixed three-tier tariff system to a spot market-based tariff system. This is one of the reasons why Denmark is able to integrate a high share of wind power.

$[62,70]$. A technical challenge was hence partly met through regulatory changes in the market system employed to create the correct incentives for producers.

2.

If Denmark subsequently supplements (and partly replaces) some of its CHP units with heat pumps and additional heat storage capacity, the integration of wind power can be raised from the present share to around 40 per cent. The first steps of such a measure are in the process of being implemented along with the increase in the share of wind power [71,72].

3.

If Denmark starts to replace fossil-fuelled cars with battery/hybrid battery electric cars, the wind power integration can be raised to 50 per cent $[71,73]$.

4. 
Additional to these measures, many other possibilities exist, such as flexible demands, hydrogen and/or similar energy carriers and various storage options, which are also presently being considered. Such measures would be able to further increase the share of wind power. E.g., as a result of a four-year research collaboration between seven Danish university departments and research institutions in the project Coherent Energy and Environmental System Analysis (CEESA - www.ceesa.dk), the following future option has been examined: On the one hand, biomass resources for energy are scarce in the long-term perspective and, on the other, transforming the transport sector into 100 per cent renewable energy is a complex process, calling for different forms of renewable energy gases and liquid fuels such as biogas, syngas and methanol. In order to balance the concern between these issues,, there is a need for transforming electricity via electrolysis and hydrogen into various forms of renewable energy gases and liquids. Consequently, in the long-term perspective, a new option arises of helping the electricity balancing by converting electricity into various gases and liquids before storing these. In the Danish system, this paves the way for utilising the substantial storage capacity already existing as part of the Danish natural gas distribution system [74].

5.

It is very important to include the small CHP plants, heat pumps and the electrification of transport as well as the wind turbines in the power balancing (i.e., the stabilisation of voltage and frequency) if the above-mentioned measures are to be successful. Again, such steps are being taken and the small CHP plants are already participating in almost all of these tasks via their participation in the following power markets: Primary automatic control (frequency), secondary automatic control (15 minutes), manual regulating power (15 minutes) and spot market (day-ahead hour market) [42,60,75].

The steps and technological options presented above represent a way of thinking of the energy system with much more sector integration than today. Already now, the power and heating sectors are well integrated in Denmark. Going from the current system to a 100 per cent renewable energy system in 2050 would require a focus on smart energy systems instead of just smart grids [41]. It is necessary to continue implementing sector integration, as this provides new opportunities for flexibility and storage or for moving demands in the energy system.

The conclusion is not only that Denmark, with its present mix of energy technologies, is able to integrate 20 per cent wind power in a way which makes it possible for our neighbouring countries to do the same, but also that Denmark has a strategy to increase this share to 50 per cent in the near future, and that the necessary measures are in the process of being researched, developed and implemented.

\section{Conclusion}

This study was motivated by incorrect claims reported on the consequences of increasing the share of wind power in Denmark. There are many technical and regulatory challenges associated with transforming any energy system based upon centralised power plants to accommodate high shares of wind power. However, the circulation of incorrect claims makes public debates and policy making on these issues 
even more complex. This article has developed and presented a new methodology that can be used to make more correct and appropriate analyses of the consequences of high wind power penetration.

For the last decade, Danish wind turbines have generated the equivalent of approx. 20 per cent of the Danish electricity demand in a normal wind year. E.g., the production in 2008 was 6,978 GWh, equal to 19.3 per cent of the electricity demand.

Our study shows that of these 6,978 GWh in 2008, one can say for a fact that a minimum of 0.1 per cent was exported and a minimum of 63 per cent was used in Denmark. Physically, no other options exist for these shares of the wind power produced. With regard to the remaining 36.9 per cent, one cannot technically, physically or from statistics of correlations over time determine which parts were exported and which were used in Denmark.

One has to establish a causal relation, which can be found by observing the market mechanisms of international electricity markets. Such an observation leads to the conclusion that the production of the last unit of electricity comes from the activated units with the highest short-term marginal production costs. On the Danish part of the Nordic grid, such units are often the Danish large-scale CHP plants. In situations with simultaneous high wind power production and high production at Danish CHP plants, the Danish system often ends up exporting electricity, while the non-CHP power plants, being located in neighbouring countries, are the ones exiting the market.

Understanding this market perspective and the structure, type and capacities of the power suppliers to the Nordic grid, it becomes evident that it is the whole system setting of:

- high wind power production in Denmark,

- competitive Danish CHP plants with relatively low costs of operation due to the supplementing income of district heating, and

- the presence of less competitive condensing mode power plants in neighbouring countries

that leads to the total Danish electricity system ending up selling and exporting in high wind power periods, while the plants closing down are located in other countries. The limited focus on partial statistical correlations and the assumption that the exported power is by definition wind power lack all acknowledgement of this understanding.

This acknowledgement is essential to the further interpretation of the potential for wind power integration. Through an understanding of these mechanisms, it becomes clear that the electricity export can only be explained in the system perspective. Important aspects of the interpretation are:

- If there had been no CHP but only condensing mode power plants in Denmark in 2008, there would probably have been close to no export this year, assuming the same quantity of wind power, 
- in other countries with no or low CHP penetration, the least competitive plants would more likely be located within the country, and periods of high wind power would, thus, lead to the closing down of such plants and not to export,

- if Denmark (or other countries) aim for more regulating power plants or ways to store or convert electricity, there is plenty of space for more wind power,

- i.e., the 'Danish case' of wind power production meeting 20-25 per cent of the electricity demand is not way an illustration of a scenario in which the limits for wind power integration have been reached.

No evidence, therefore, supports the claim that approximately half of the Danish electricity produced is exported. On the contrary, it could be claimed that the high share of Danish wind power has made it possible for existing CHP units and condensing units to increase their export to neighbouring countries. This possibility has been exploited due to the relatively low marginal costs of these plants on the market.

Neither the hourly production statistics nor the market-based argument presented in this report can claim to be an in-depth analysis of the technical challenges of integrating large amounts of wind power. There is no doubt that the wind power in Denmark has pushed the traditional power units further up the merit order and reduced their earning potential. Also hydro power with storage capacity in Norway and Sweden has proved to be a cost-efficient way to integrate wind power on market terms.

The conclusion is that Denmark has demonstrated the ability to integrate a high share of wind power by use of local resources and the international market in a way which enables our neighbouring countries to do the same. The present Danish share of wind power (in 2008) of 20 per cent in no way indicates an upper limit for wind power integration. On the contrary, Denmark has a strategy to increase this share to 50 per cent and the necessary measures are in the process of being implemented.

From an energy policy perspective, the work also demonstrates that there is room for ambitious expansion plans in most places. An expansion to the present Danish level of 20-25 per cent wind power penetration in other countries would not be beyond the realms of the technically possible with a corresponding important decrease in fossil fuel consumption and green-house gas emissions.

The cost of $\mathrm{CO}_{2}$ reduction by use of wind power in the period 2004-2008 was only 20 $€ /$ ton. Furthermore, no taxes are recycled to support the established wind power in Denmark ${ }^{2}$.

Danish wind turbines are given a subsidy via the electricity price, which is paid by the electricity consumers. In the years 2004-2008, such a subsidy increased consumer prices by $0.54 € \mathbb{C} / \mathrm{kWh}$ on average. On the other hand, the same electricity consumers also benefitted from the wind turbines, since the wind power decreased the electricity market prices on Nord Pool. On average, such an effect decreased the consumer prices by 0.27

\footnotetext{
${ }^{2}$ Only with regard to research, development and demonstration are taxpayers involved in payment to wind power as well as other new technologies. The payment for already established wind turbines is made by power consumers.
} 
$€ \mathbb{C} / \mathrm{kWh}$ during 2004-2008 and, consequently, the net influence during this period increased consumer prices by only $0.27 € \mathbb{C} / \mathrm{kWh}$, equal to only $1-3$ per cent of the final consumer prices. In 2008, the net influence of wind power actually decreased the

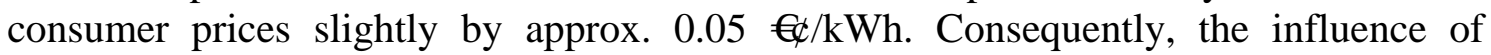
Danish wind turbines on the consumer electricity prices is negligible.

Moreover, the payment to wind power does not make Danish electricity prices any higher than those in other countries, as sometimes claimed in the public debate. In fact, Danish electricity prices (excluding taxes and VAT), including payment for 20 per cent wind power, are among the lowest in Europe.

\section{Acknowledgements}

This study is part of the research project Coherent Energy and Environmental System Analysis (CEESA), partly financed by the Danish Council for Strategic Research. The rest has been financed by the companies and institutions of the authors.

This study has been initiated and conducted solely on the initiative of the authors and involves no additional financing or involvement by any political or commercial interests.

The methodology and results of this paper have previously been published online in the report “Danish Wind Power. Export and Cost” (2010) [76]. 


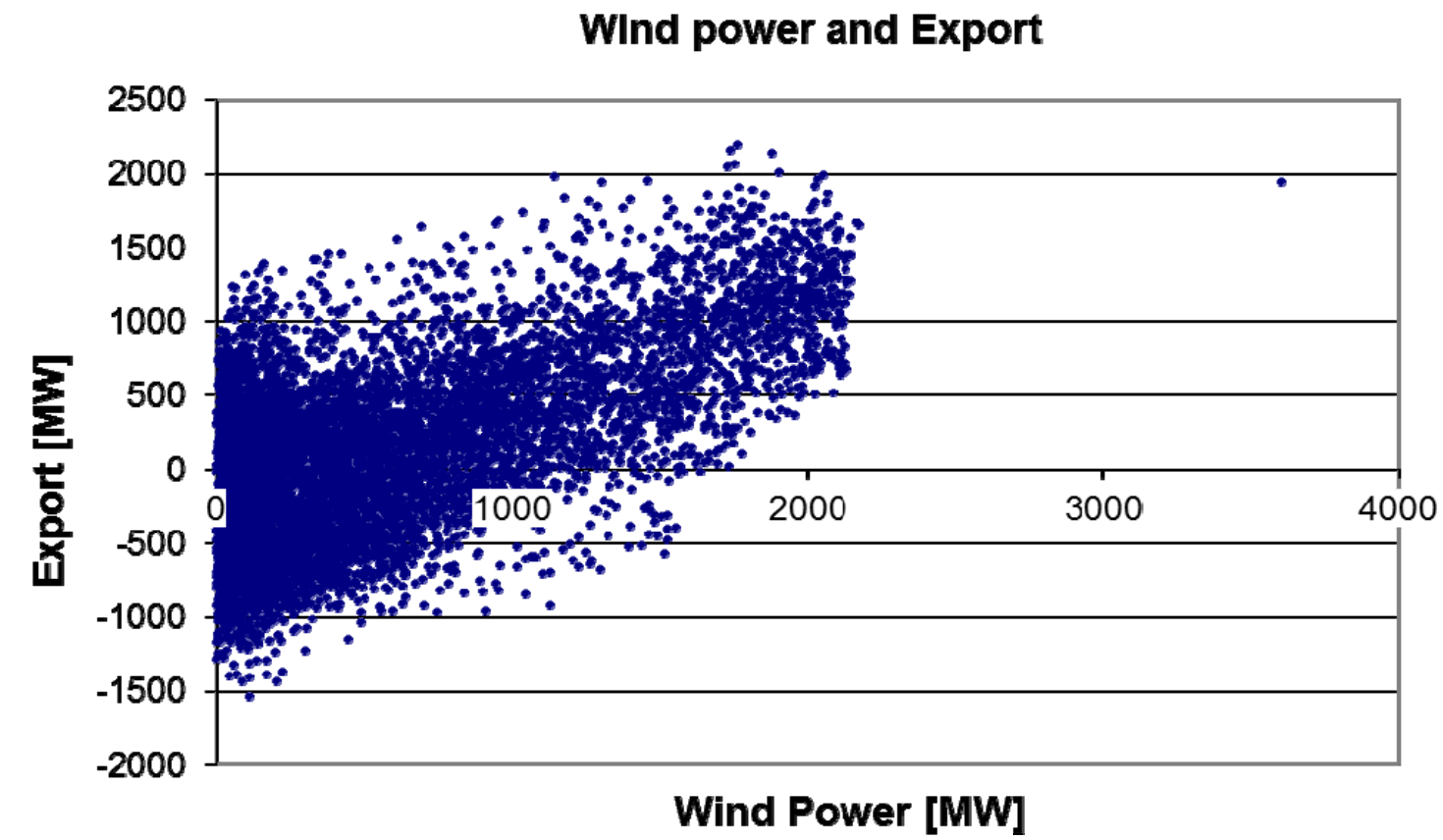

Fig 1: Hourly Wind Power and Export in Western Denmark 2008. Based on data from [50] 


\section{Large Power Plants and Export in 2008}

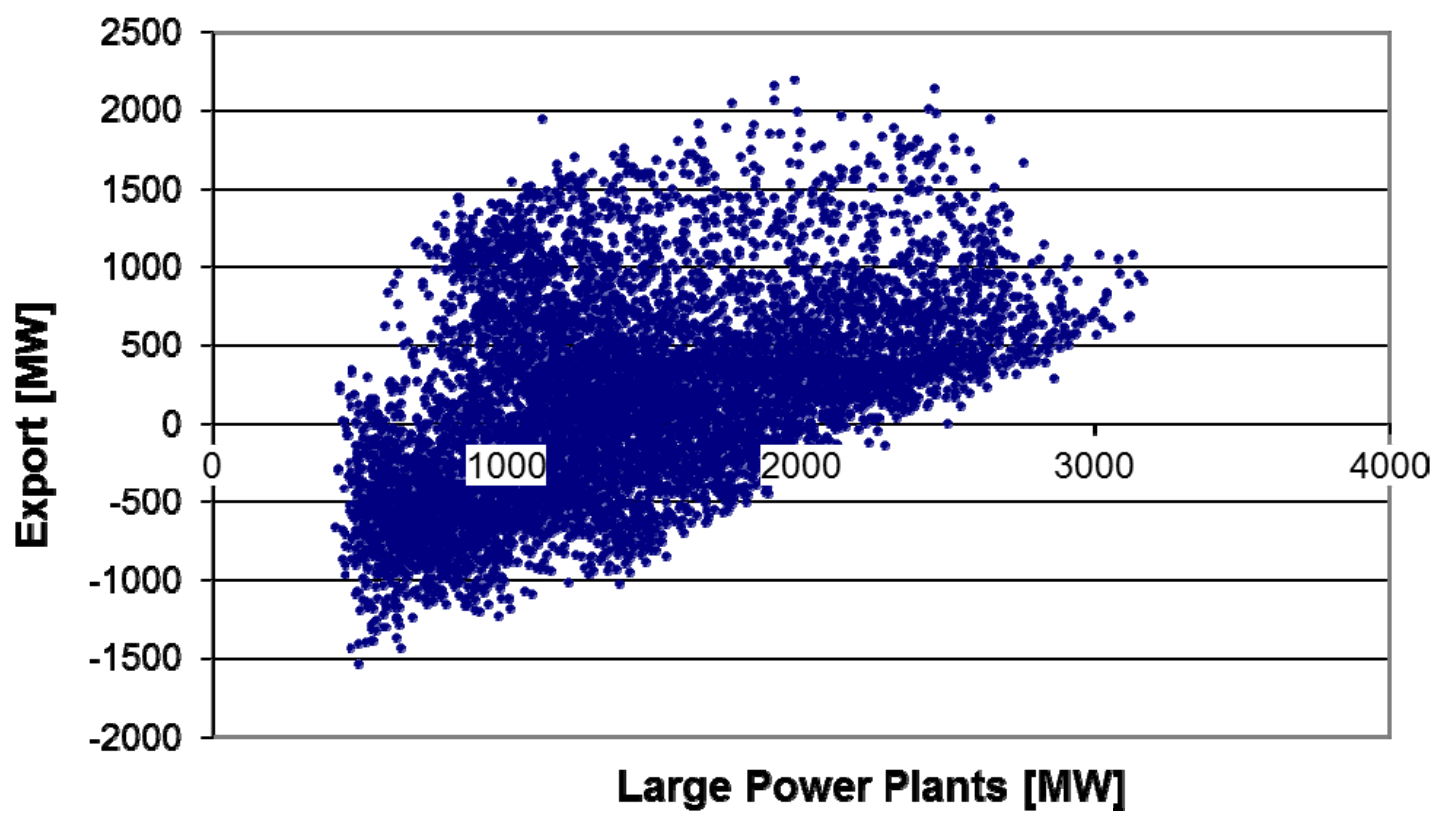

Fig 2: Hourly production from Large Power Plants and Export in Western Denmark 2008. Based on data from[50]. 


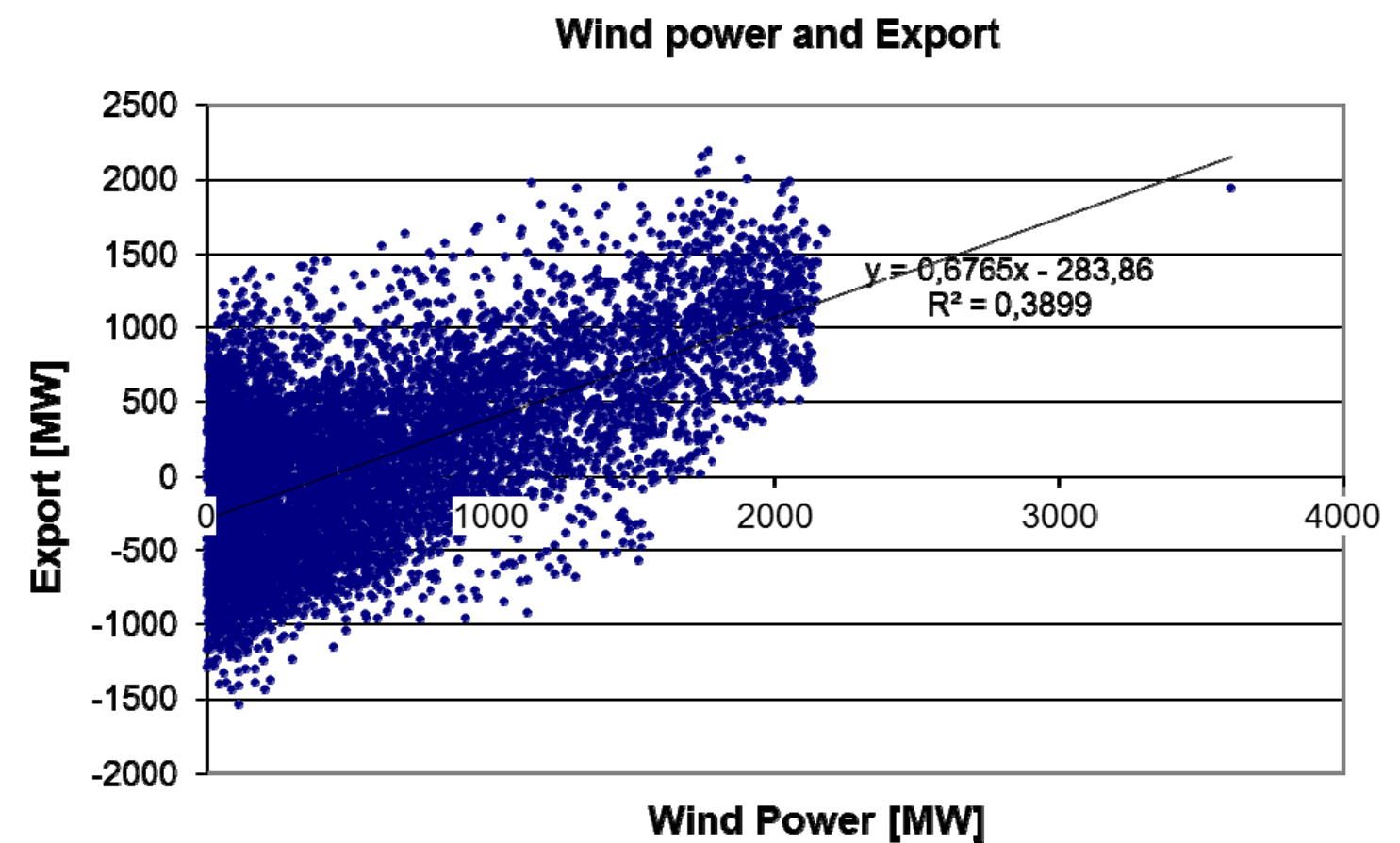

Fig 3: Statistical analysis of the correlation between wind power and export in 2008. Based on data from [50]. 


\section{Large Power Plants and Export in 2008}

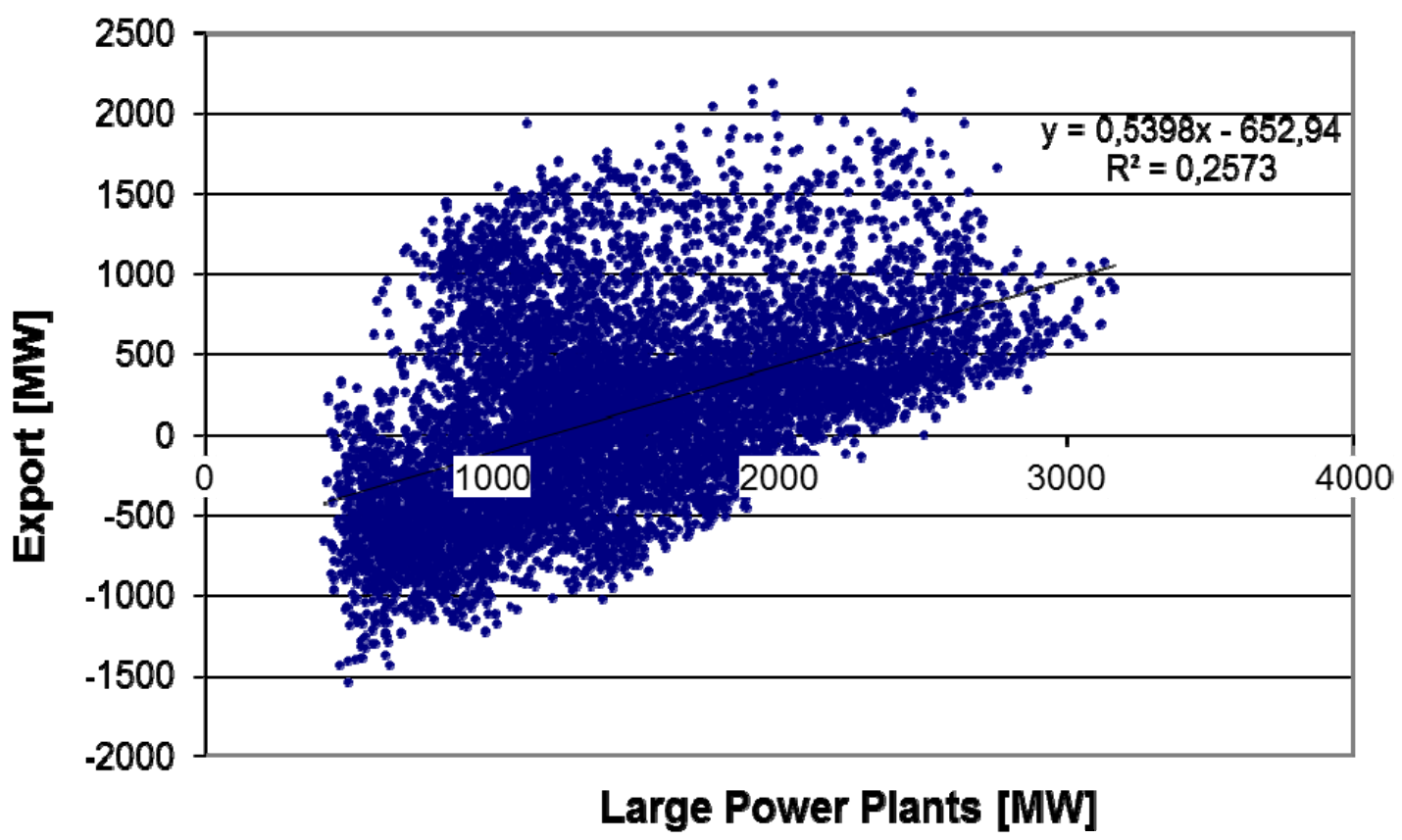

Fig 4: Statistical analysis of the correlation between the production on large power plants and export in 2008. Based on data from [50]. 


\section{Small CHP Plants and Export in 2008}

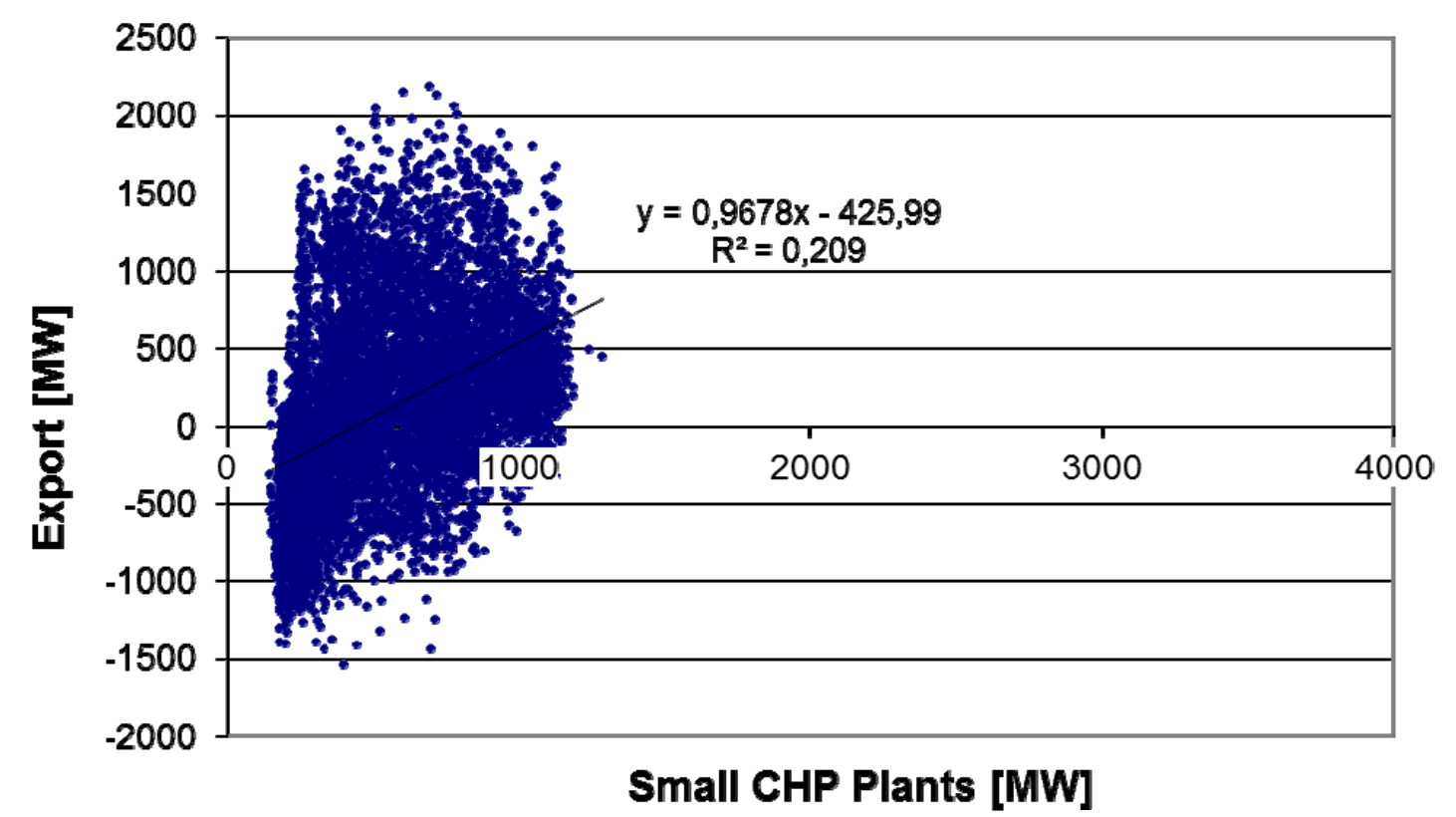

Fig 5: Statistical analysis of the correlation between the production on small CHP plants and export in 2008. Based on data from [50]. 


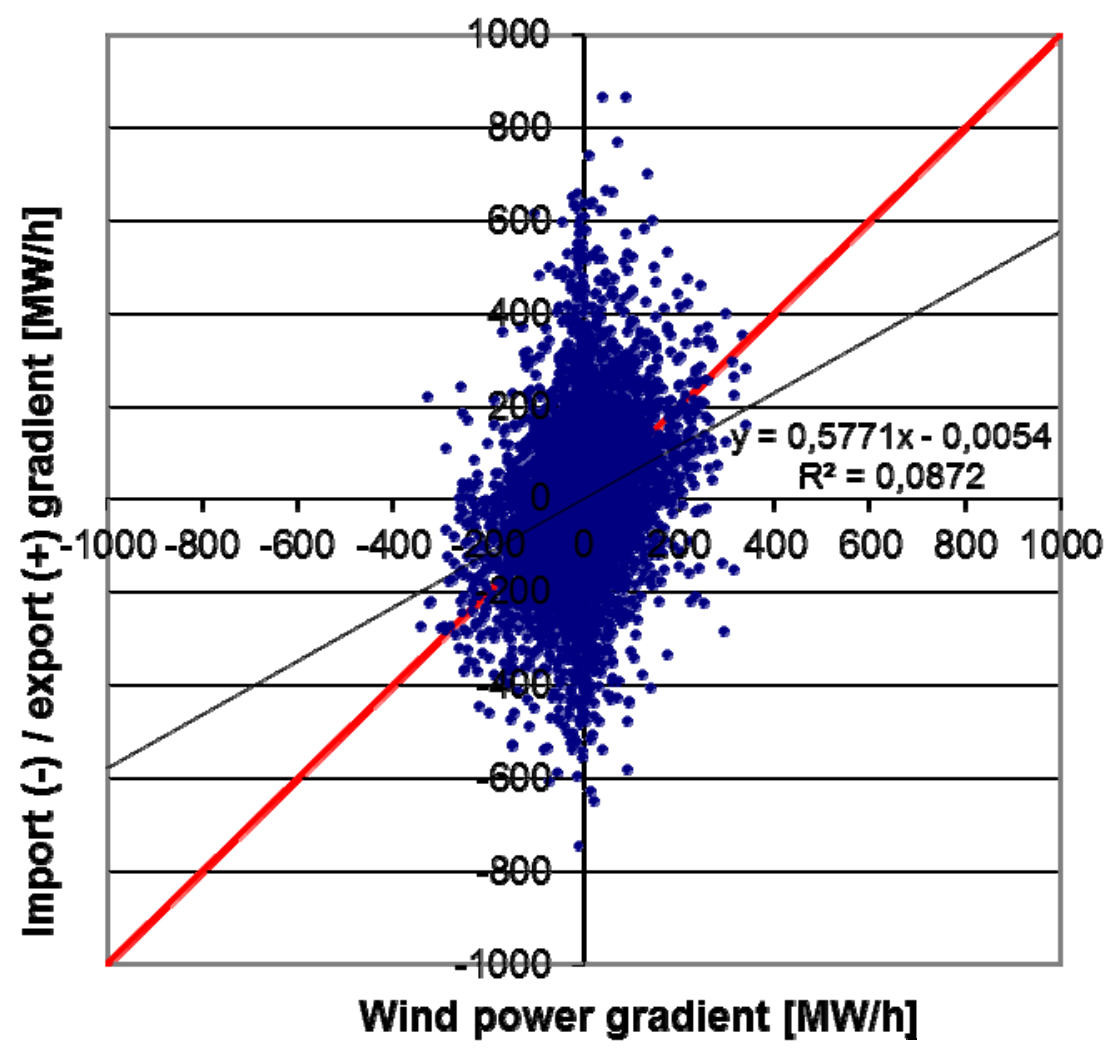

Fig 6: X,Y plots of hourly changes in export and changes in wind power in Western Denmark in 2008. 


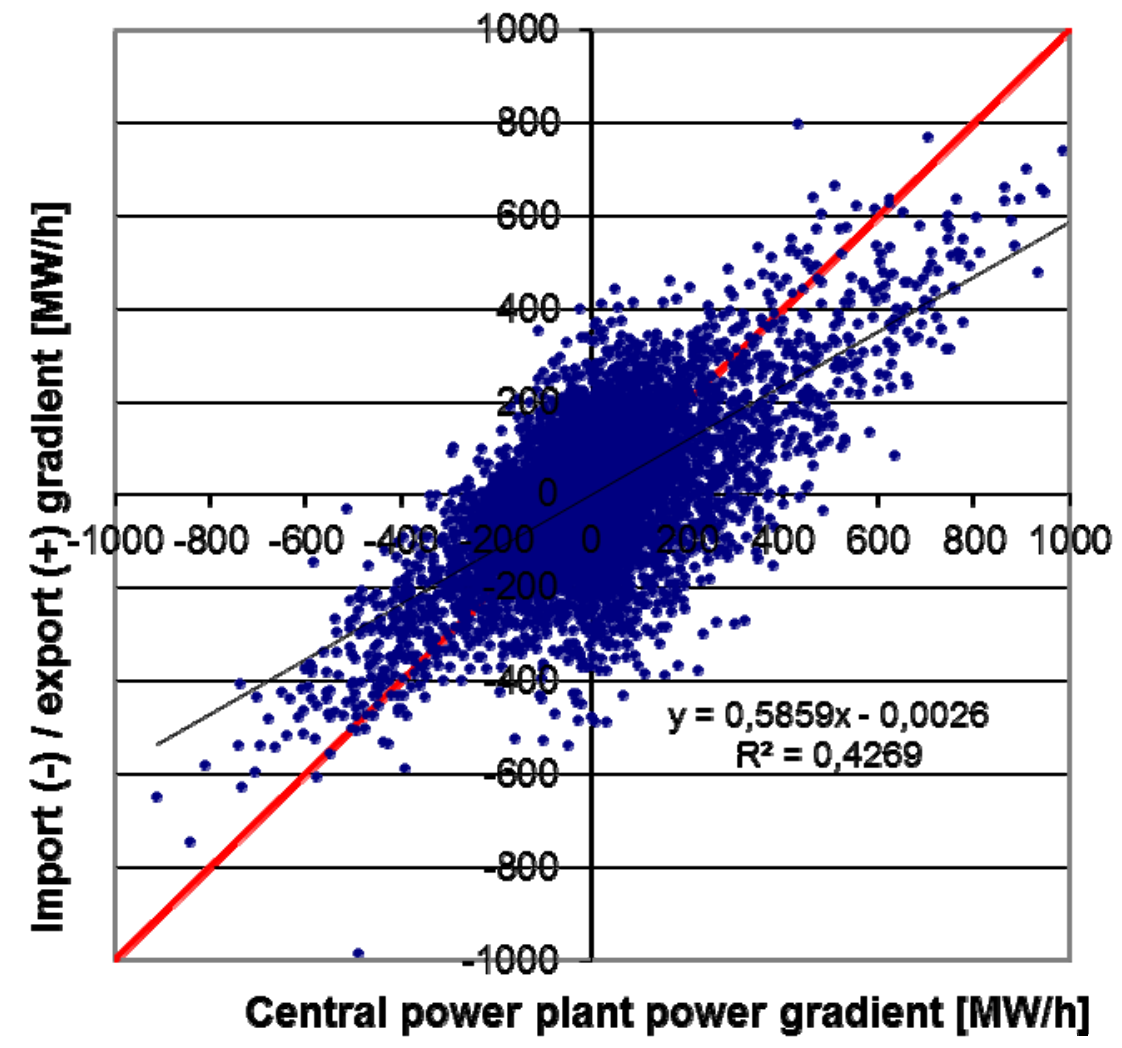

Fig 7: X,Y plots of hourly changes in export and changes in the production on large power plants in Western Denmark in 2008. 

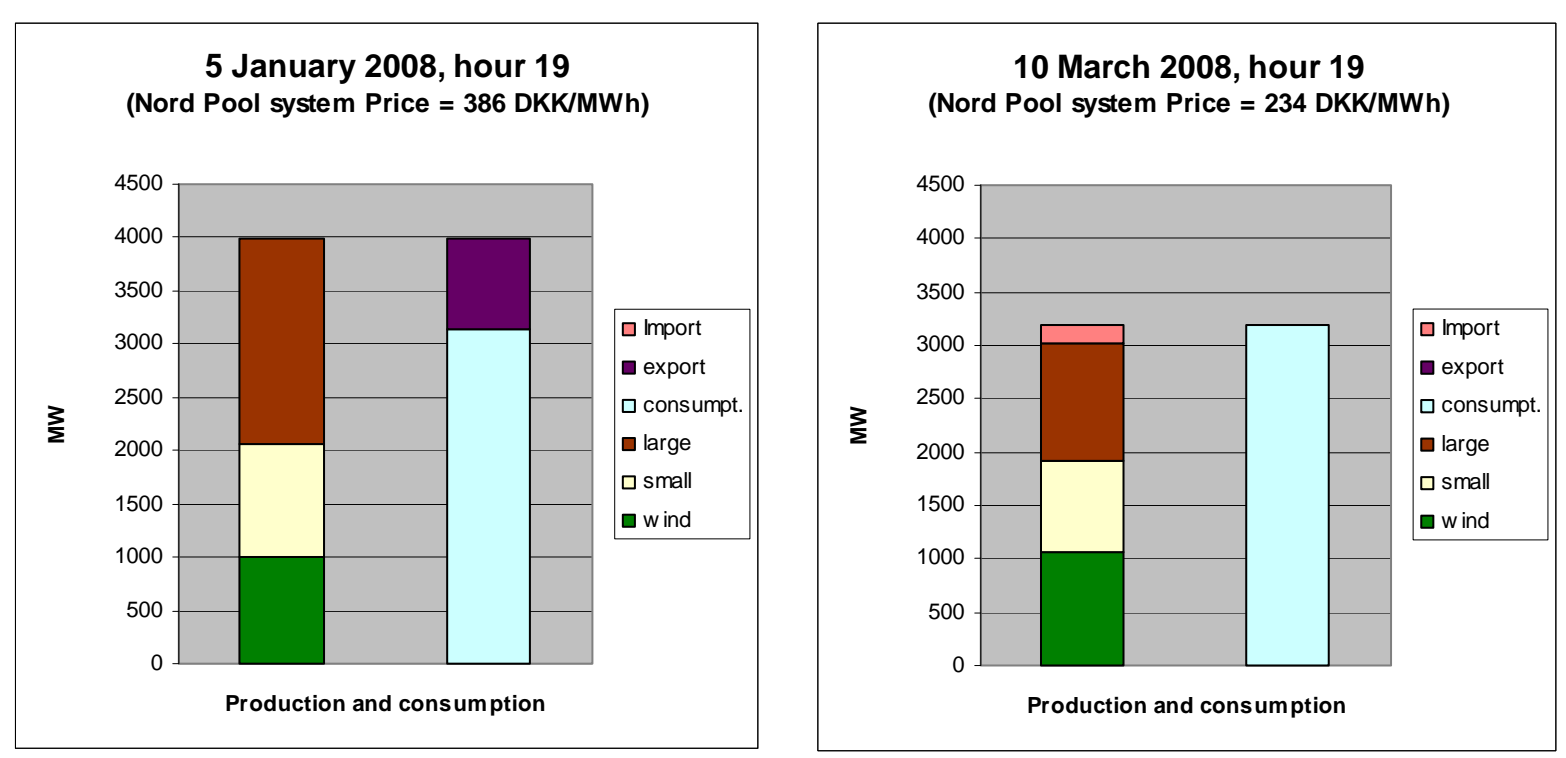

Fig. 8: Demand and production of electricity in Western Denmark in two 2008 situations with the same wind power production but different export figures. 


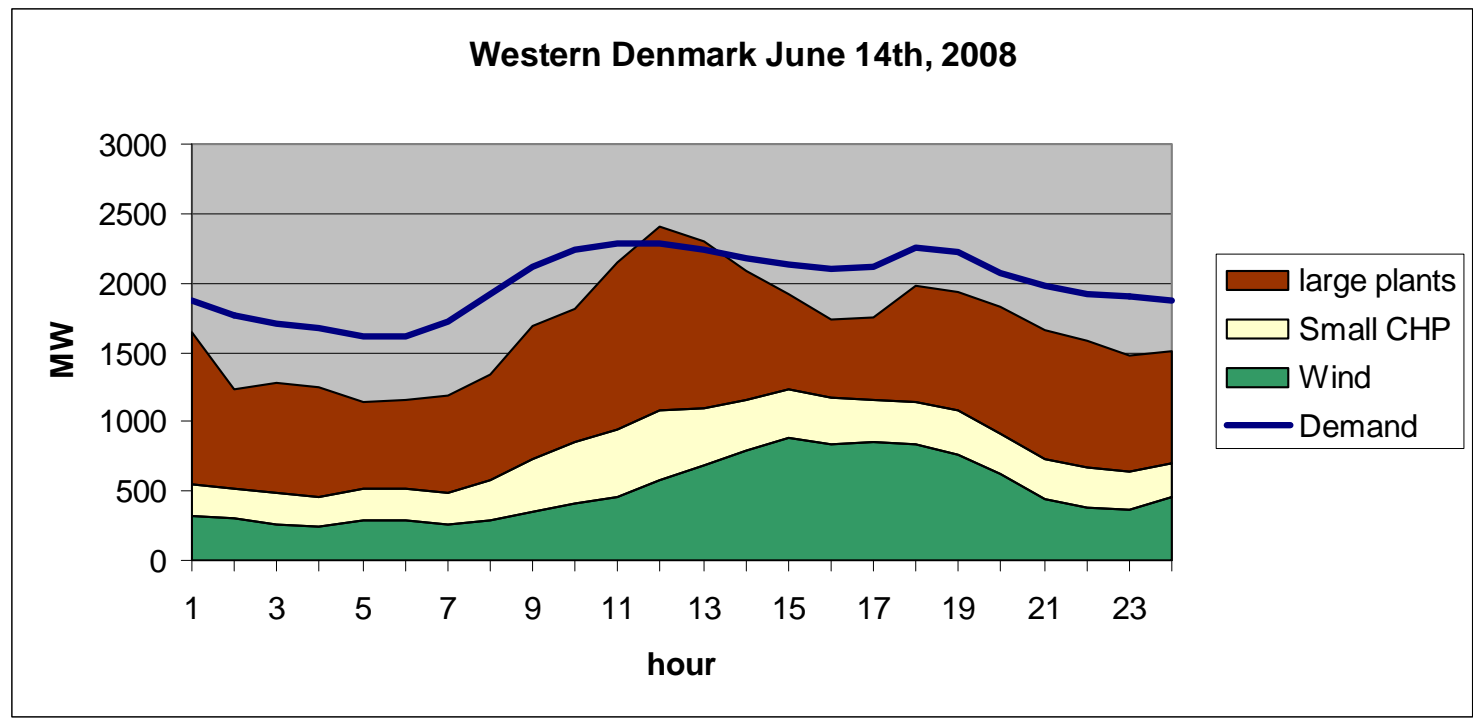

Fig. 9: Actual Danish electricity demand and production on June $14^{\text {th }}, 2008$. 


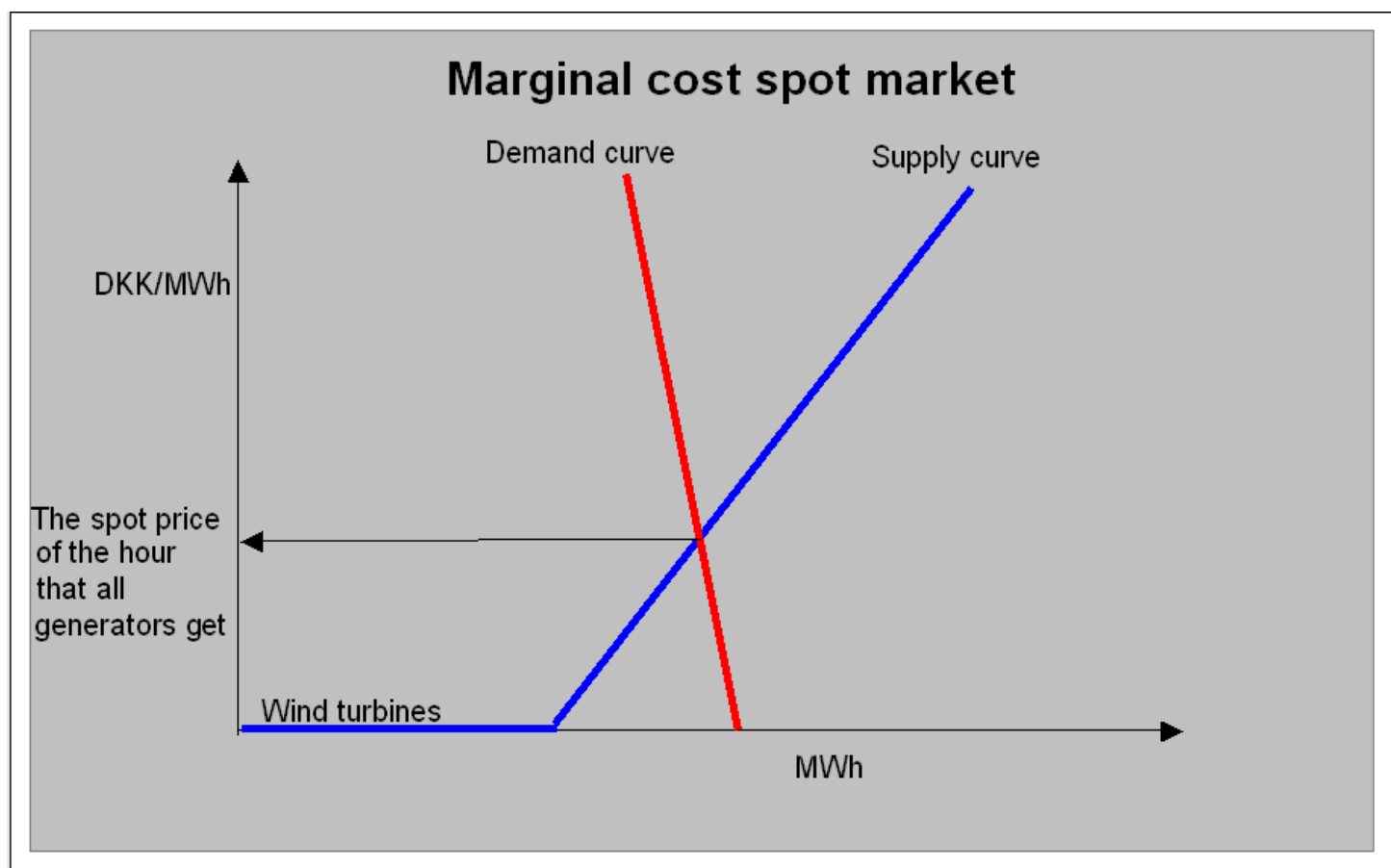

Fig. 10: Price setting in a marginal cost electricity spot market. 


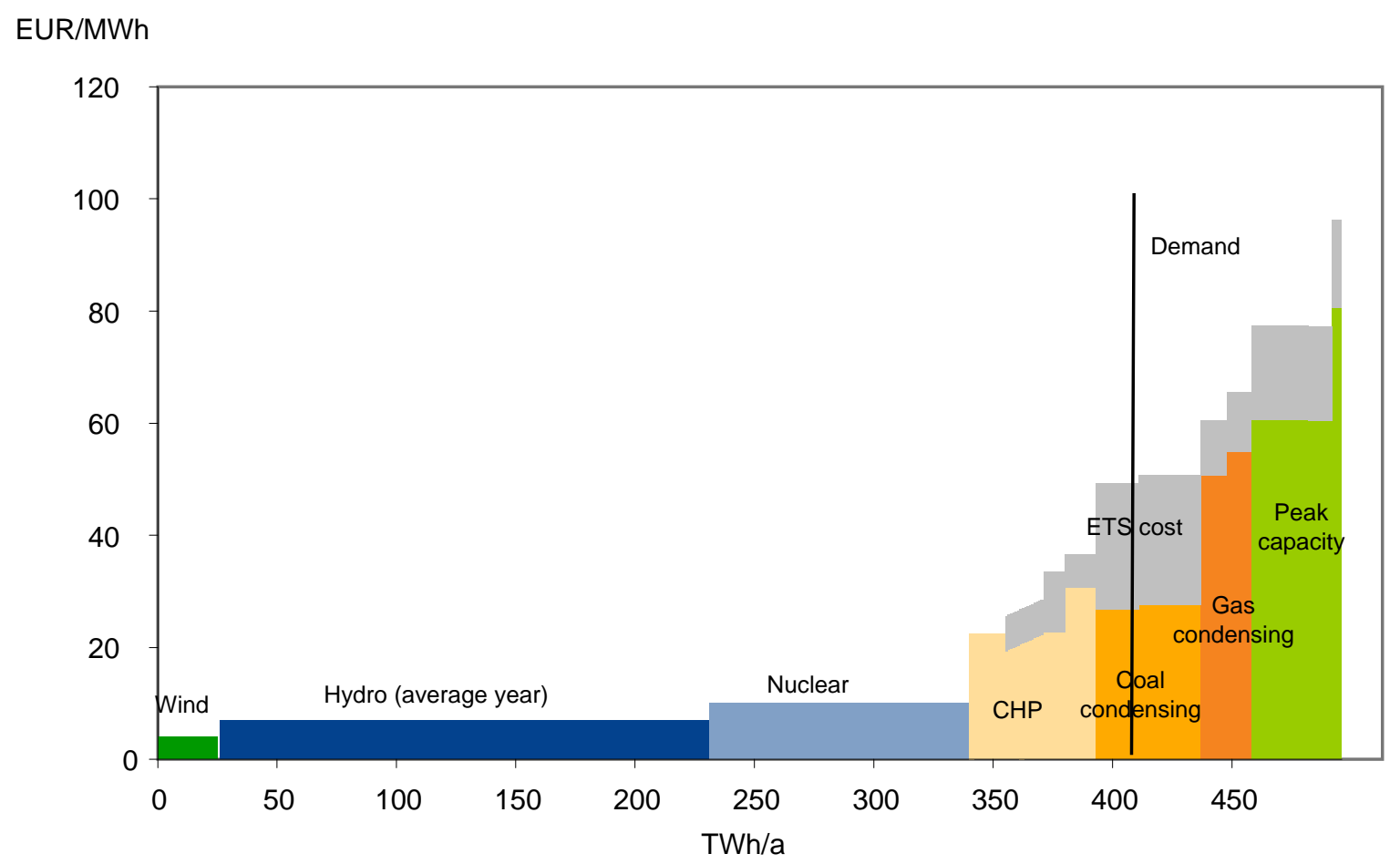

Fig 11: Merit order of marginal production on the Nordic Nord Pool Market. ETS shows the influence of the EU Emission Trading System on the production costs. Source: [77] 


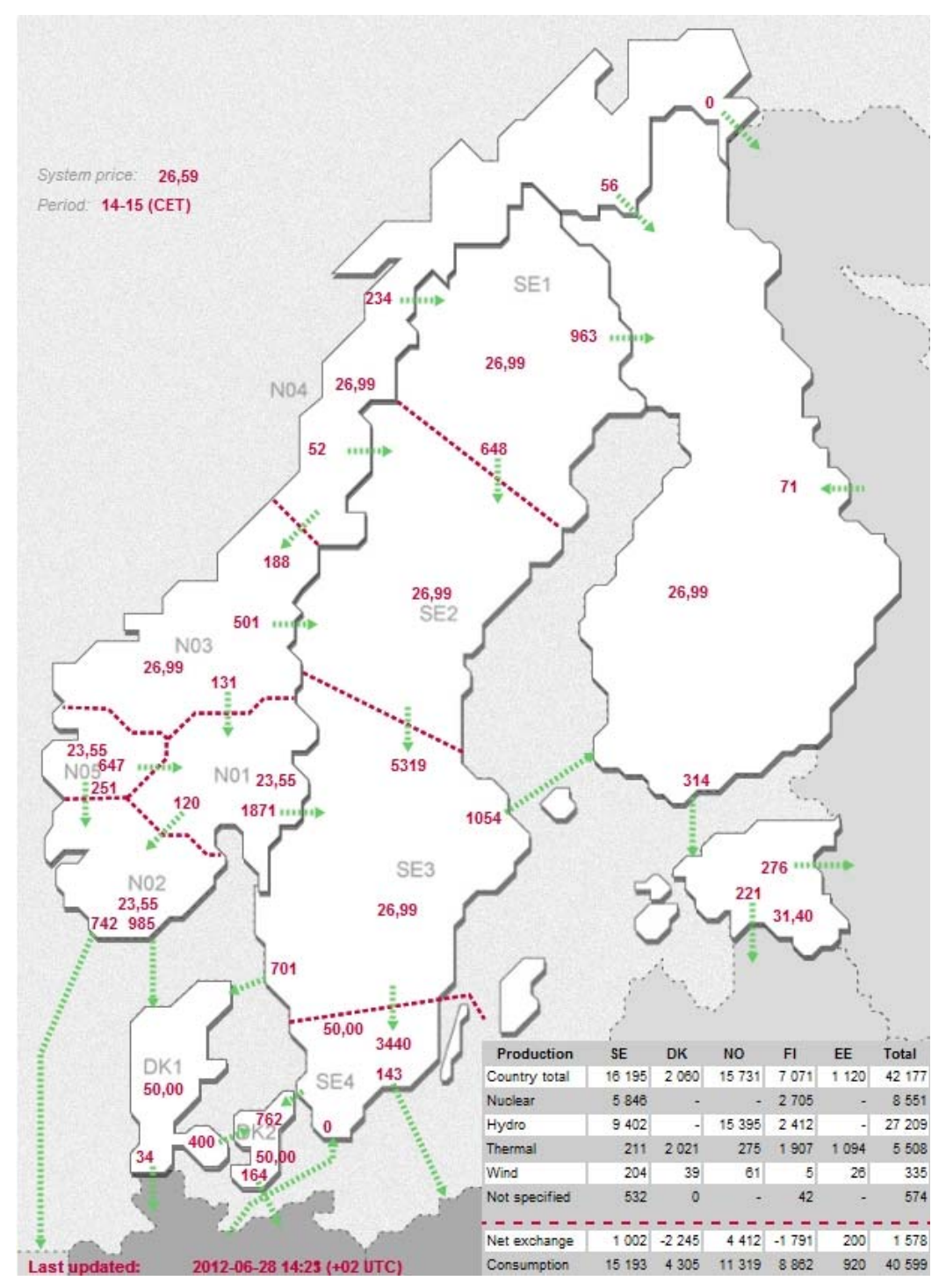

Fig. 12: Denmark (lower right) is situated between continental Europe and the Scandinavian Peninsula. For the years in which these analyses were made, Western Denmark was connected to Germany, Sweden and Norway, while Eastern Denmark was connected to Sweden and Germany only. Today, the two parts of Denmark are connected via a DC line. The map also indicates the price areas of the Nord Pool electricity market with prices in EUR/MWh as well as flows between the price areas. Source: [78] 


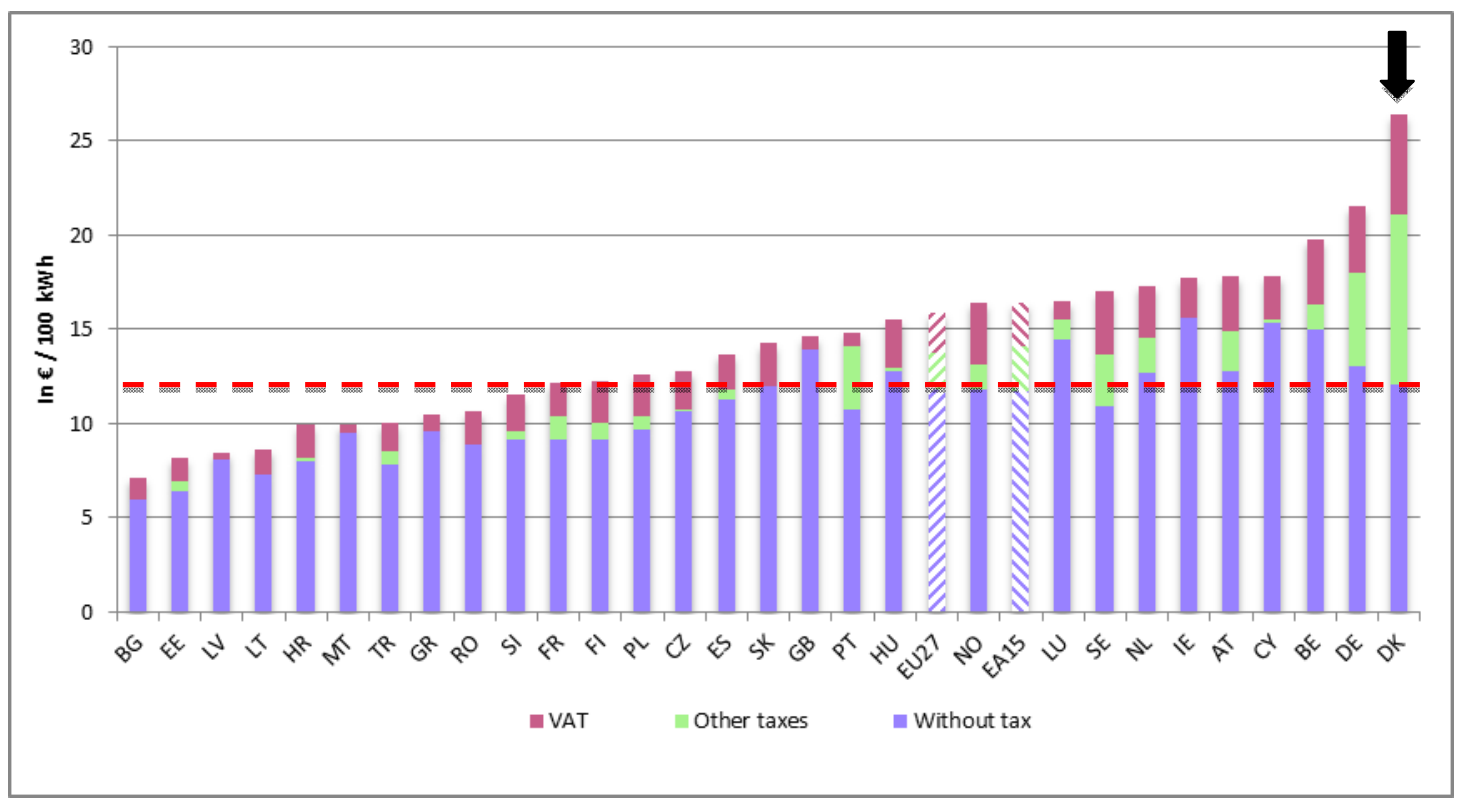

Fig. 13 Electricity prices for household consumers (Band DC - Annual consumption between 2500 and $5000 \mathrm{kWh}$ ) the first semester of 2008. Three costs are shown: Without taxes (The actual electricity price (universal service obligation), subscription fee of actual electricity, local grid tariff, subscription fee to power grid company, regional transmission tariff, grid tariff, system tariff, Public Service Obligation tariff) Other taxes (Electricity tax, electricity distribution subscription, energy saving subscription, energy saving tax) and Value Added Tax (VAT). The black arrow shows Denmark; the horizontal line shows Danish electricity prices excl. VAT and taxes. The chart is constructed using data from [79] and corresponds to graphs found in both [44] and [80], though the horizontal line is not included in [44]and neither lines nor arrow are found in [80].

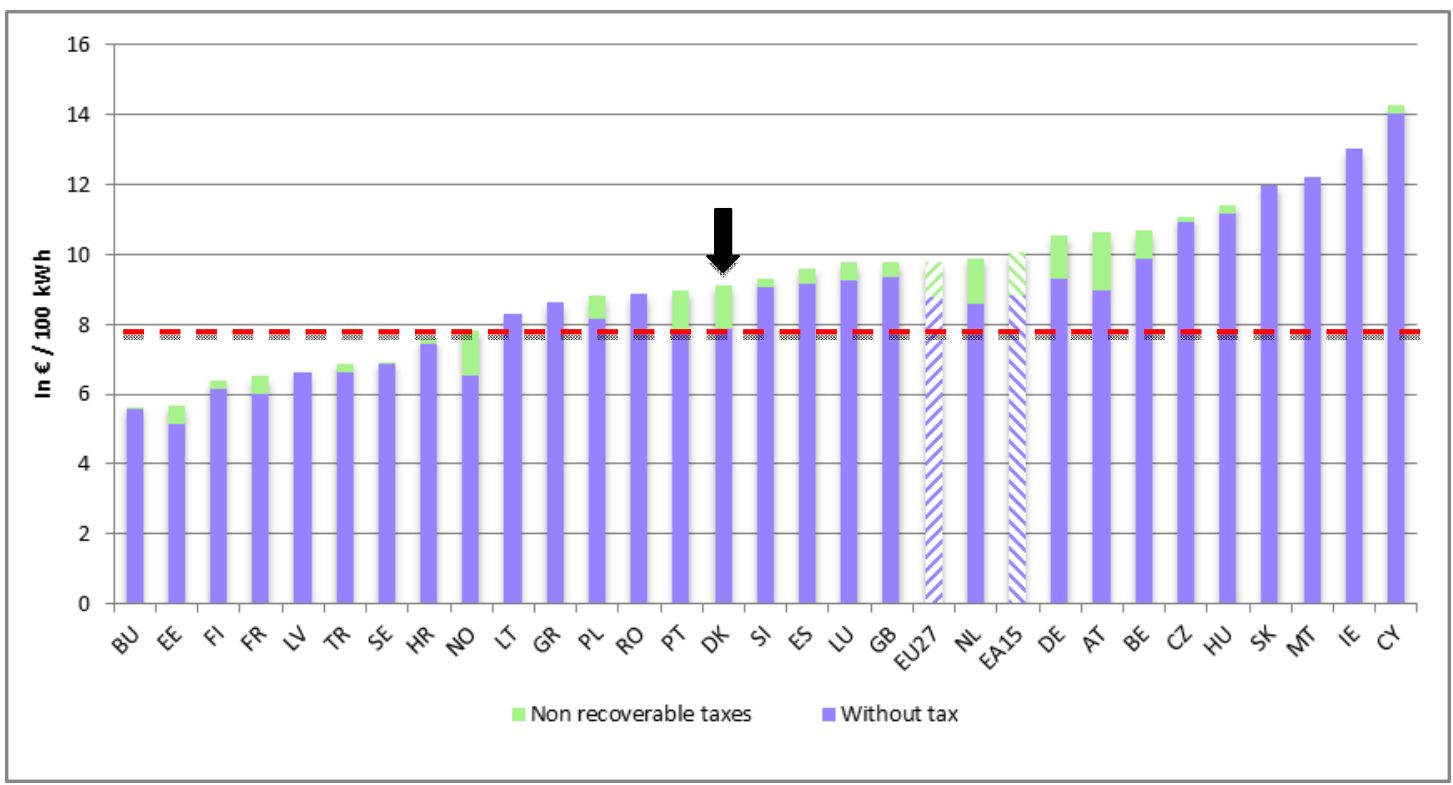

Fig. 14 Electricity prices for industrial consumers (Band IC - Annual consumption between 500 and $2500 \mathrm{MWh}$ ) the first semester of 2008. Two costs are shown: Without taxes (The actual electricity price (universal service obligation), subscription fee of actual electricity, local grid tariff, subscription fee to power grid company, regional transmission tariff, grid tariff, system tariff, Public Service Obligation tariff) and Non-recoverable taxes (Energy saving tax, electricity distribution subscription). The black arrow shows Denmark; the horizontal line shows Danish electricity prices excl. VAT and taxes. The chart 
is constructed using data from [81] and corresponds to graphs found in both [44]and [80], though the horizontal line is not included in [44] and neither lines nor arrow are found in [80]. 


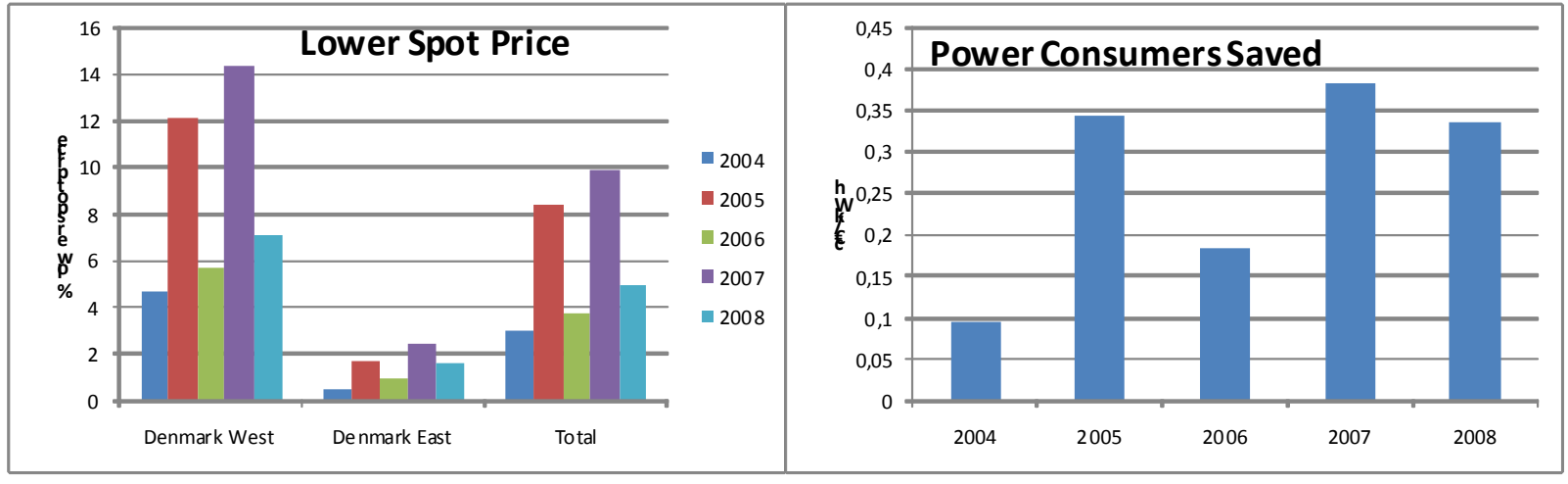

Fig. 15: Price impact of wind power on the Nord Pool market, 2004-2008. Source: Poul Erik Morthorst 2009 updated with 2007 and 2008 figures from [82,83]. 
Increasing Increasing Decreasing Decreasing Increasing Increasing Decreasing Decreasing export and export and export and export and export and export and export and export and Positive Positive decreasing increasing decreasing increasing decreasing increasing decreasing increasing feedback, feedback, $\begin{array}{lllllll}\text { wind wind wind wind } & \text { PP } & \text { PP } & \text { PP } & \text { PP } & \text { wind [\%] PP [\%] }\end{array}$ power power power power production production production production

\begin{tabular}{lccccccccc}
\hline $\begin{array}{l}\text { No. of } \\
\text { hours }\end{array} 1.817$ & 2.576 & 2.613 & 1.777 & 1.632 & 2.761 & 2.993 & 1.397 & $59 \%$ & $66 \%$ \\
$\begin{array}{l}\text { GWh } \\
\text { power }\end{array}$ & 1.593 & 1.705 & 898 & 1.036 & 1.553 & 1.667 & 936 & $64 \%$ & $62 \%$
\end{tabular}

Table 1: Distribution of annual number of hours and production viz. Figures 6 and 7 


\begin{tabular}{|c|c|c|c|c|c|c|}
\hline NordPool Sp & & & & & & \\
\hline $\begin{array}{l}\text { Simple exam } \\
\text { No connection }\end{array}$ & $\begin{array}{l}\text { of spot trad } \\
\text { tween the two }\end{array}$ & $\begin{array}{l}\text { ain hol } \\
\text { is }\end{array}$ & ur tomorrow & & & \\
\hline $\begin{array}{l}\text { Buying offer: } \\
\text { Sale offers: }\end{array}$ & \begin{tabular}{|l} 
Price area 1 \\
\\
Wind turbines \\
Power plant 1 \\
Power plant 2 \\
Power plant 3 \\
Power plant 4
\end{tabular} & $\begin{array}{r}\text { Amount } \\
\text { [MWh] } \\
2000 \\
\\
1500 \\
500 \\
500 \\
500 \\
500\end{array}$ & $\begin{array}{r}\text { Bidding price } \\
\text { [DKK/MWh] } \\
\text { Priceindep. } \\
\\
200 \\
250 \\
275 \\
325\end{array}$ & \begin{tabular}{|l} 
Price area 2 \\
\\
Power plant 5 \\
Power plant 6 \\
Power plant 7 \\
Power plant 8 \\
Power plant 9 \\
Power plant 10
\end{tabular} & $\begin{array}{r}\text { Amount } \\
\text { [MWh] } \\
\\
2500 \\
\\
500 \\
500 \\
500 \\
500 \\
500 \\
500\end{array}$ & $\begin{array}{r}\text { Bidding price } \\
\text { [DKK/MWh] } \\
\text { Priceindep. } \\
50 \\
100 \\
350 \\
400 \\
435 \\
450\end{array}$ \\
\hline $\begin{array}{l}\text { Spot price of t } \\
\text { hour }\end{array}$ & & & 200 & & & 435 \\
\hline
\end{tabular}

Table 2: Example of a spot trade during a certain hour tomorrow. No connection between the two price areas. The shaded area indicates the marginal price of the hour and, thus, the marginal supplier unit. 


\begin{tabular}{|c|c|c|c|c|c|c|}
\hline \multirow{2}{*}{\multicolumn{7}{|c|}{$\begin{array}{l}\text { NordPool Spot } \\
\text { Simple example of spot trade in a certain hour tomorrow } \\
1000 \text { MW interconnector between the two price areas }\end{array}$}} \\
\hline & & & & & & \\
\hline $\begin{array}{l}\text { Buying offer: } \\
\text { Sale offers: }\end{array}$ & \begin{tabular}{|l} 
Price area 1 \\
\\
Wind turbines \\
Power plant 1 \\
Power plant 2 \\
Power plant 3 \\
Power plant 4
\end{tabular} & $\begin{array}{r}\begin{array}{r}\text { Amount } \\
{[\mathrm{MWh}]}\end{array} \\
2000 \\
\\
1500 \\
500 \\
500 \\
500 \\
500\end{array}$ & $\begin{array}{r}\text { Bidding price } \\
\text { [DKK/MWh] }\end{array}$ & \begin{tabular}{|l} 
Price area 2 \\
\\
Power plant 5 \\
Power plant 6 \\
Power plant 7 \\
Power plant 8 \\
Power plant 9 \\
Power plant 10
\end{tabular} & $\begin{array}{r}\begin{array}{r}\text { Amount } \\
\text { [MWh] }\end{array} \\
2500 \\
\\
500 \\
500 \\
500 \\
500 \\
500 \\
500\end{array}$ & $\begin{array}{r}\text { Bidding price } \\
\text { [DKK/MWh] } \\
\text { Priceindep. } \\
50 \\
100 \\
350 \\
400 \\
435 \\
450\end{array}$ \\
\hline \multicolumn{2}{|c|}{$\begin{array}{l}\text { Spot price of the } \\
\text { hour }\end{array}$} & & 275 & & & 350 \\
\hline
\end{tabular}

Table 3: Example of a spot trade during a certain hour tomorrow. 1000 MW connection between the two price areas. 


\begin{tabular}{lcc}
\hline Country & $\begin{array}{c}\text { Industrial electricity price } \\
\text { excluding taxes }[€ \notin / \mathrm{kWh} \text { ] }\end{array}$ & $\begin{array}{c}\text { Renewable energy share of } \\
\text { electricity consumption [\%] }\end{array}$ \\
\hline Denmark & 7.85 & 29 \\
Latvia & & (hereof 19.6 wind power) \\
Greece & 8.29 & 36 \\
Romania & 8.6 & 7 \\
Slovakia & 8.9 & 27 \\
Malta & 11.97 & 17 \\
Ireland & 12.21 & 0 \\
Portugal & 13.02 & 9 \\
Czech republic & 8.95 & 30 \\
Cyprus & 10.95 & 5 \\
Hungary & 14.05 & 0 \\
Slovenia & 11.24 & 5 \\
Luxembourg & 9.04 & 22 \\
UK & 9.99 & 4 \\
Spain & 9.37 & 5 \\
Belgium & 9.15 & 20 \\
Poland & 9.88 & 4 \\
Germany & 8.14 & 15 \\
Netherlands & 9.29 & 8 \\
Austria & 8.6 & 60 \\
\hline
\end{tabular}

Table 4: Renewable energy shares and industrial electricity prices in 20 EU countries. Source: Own calculations based on Eurostat data in focus 45/2008. 


\begin{tabular}{lcc}
\hline Year & $\begin{array}{l}\text { Consumer payment to wind power } \\
\text { for } \mathrm{CO}_{2} \text { free electricity }[\mathrm{M} \mathrm{DKK}]\end{array}$ & $\begin{array}{l}\text { Consumer payment to wind } \\
\text { power for } \mathrm{CO}_{2} \text { free electricity } \\
{[\mathrm{M} €]}\end{array}$ \\
\hline \multicolumn{2}{c}{} \\
2004 & 1440 & 193.3 \\
2005 & 1690 & 226.85 \\
2007 & 1085 & 145.6 \\
2008 & 1875 & 251.7 \\
& 720 & 96.6 \\
\hline
\end{tabular}

Table 5: Extra payment for $\mathrm{CO}_{2}$ free wind energy. Source: Information from Energinet.dk 


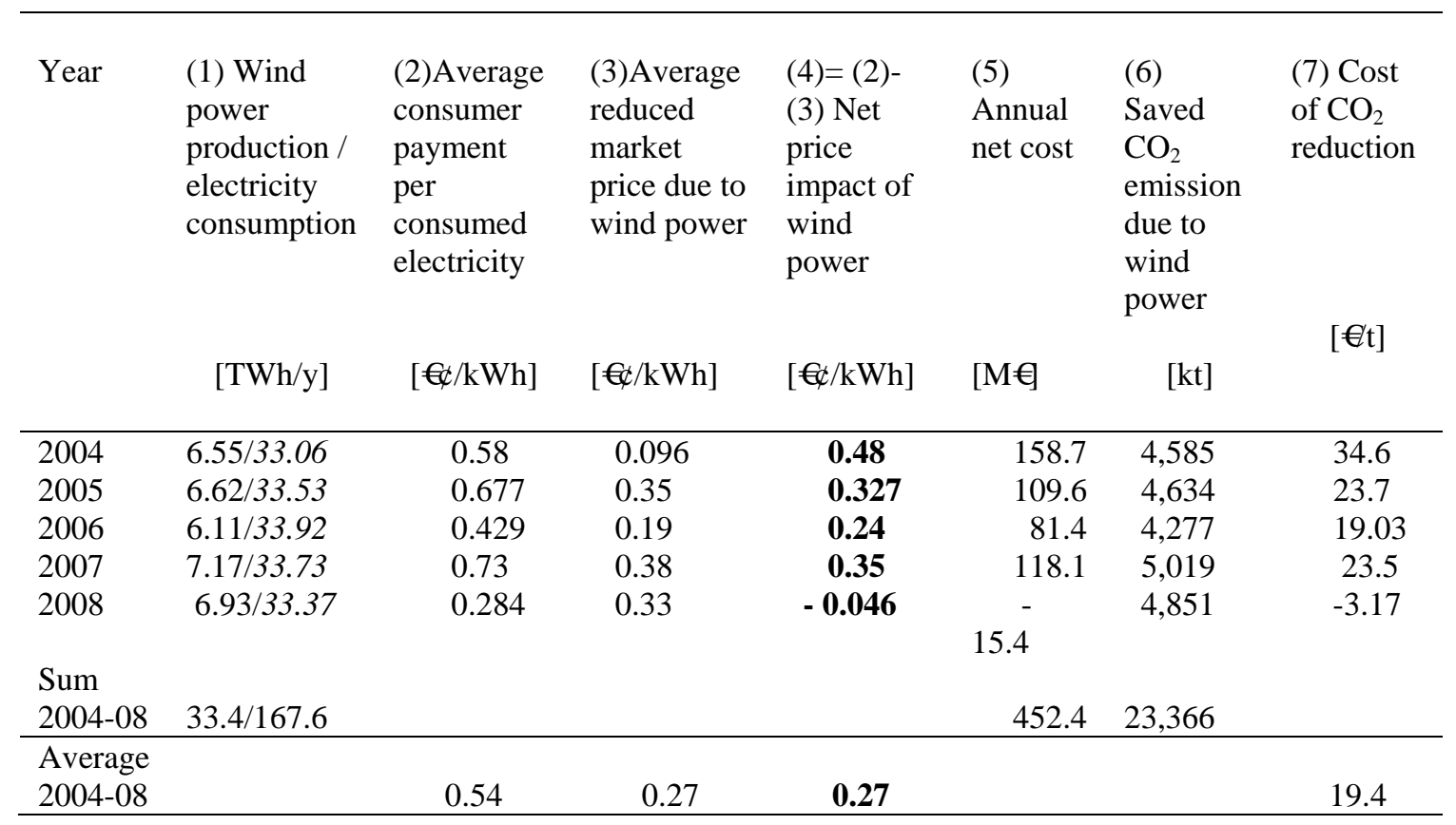

Table 6: Price and $\mathrm{CO}_{2}$ effects of wind power production 2004-2008. Source: Column (2) calculations based on data sent from Energinet.dk. Column (3) based on data from P.E. Morthorst, and [83]. 


\section{References}

[1] Federal Ministry of Economics and Technology. Energy Concept. 2010;

[2] Department of Energy and Climate Change. Planning our electric future: a White Paper for secure, affordable and low-carbon electricity. 2011;

[3] Regeringskansliet. The Swedish National Action Plan for the promotion of the use of renewable energy in accordance with Directive 2009/28/EC and the Commission Decision of 30.06.2009. 2010;

[4] Rosager F, Lund H. Analyse af eloverløbs- og elkvalitetsproblemer. Bornholms Amt; 1986.

[5] Lund H. Implementaring af bæredygtige energisystemer (Implementation of Sustainable Energy Systems). PhD dissertation. Institut for Samfundsudvikling og Planlægning, Aalborg Universitet, Skriftserie nr. 50; 1990.

[6] Illum K, Lund H. LOCUS-systems: Local Cogeneration Utility Systems for efficient Utilization of Windpower. Proceedings from European Wind Energy Conference, Rome 7-9 October 1986;329-331.

[7] Lund H. Excess Electricity Diagrams and the Integration of Renewable Energy. International Journal of Sustainable Energy 2003;23(4):149-156.

[8] Lund H. Editorial, Distributed Generation. International Journal of Sustainable Energy 2003;23(4):145-147.

[9] Orecchini F, Santiangeli A. Beyond smart grids - The need of intelligent energy networks for a higher global efficiency through energy vectors integration. International Journal of Hydrogen Energy 2011;36(13):8126-8133.

[10] Crossley P, Beviz A. Smart energy systems: Transitioning renewables onto the grid. Renewable Energy Focus 2009;11(5):54-59.

[11] Maarten W. The research agenda on social acceptance of distributed generation in smart grids: Renewable as common pool resources. Renewable and Sustainable Energy Reviews(0):

[12] Matthias W. The Smart Grid - A saucerful of secrets? Applied Energy 2011;88(7):2509-2518.

[13] Wu Yn, Chen J, Liu Lr. Construction of China's smart grid information system analysis. Renewable and Sustainable Energy Reviews(0):

[14] Østergaard PA. Comparing electricity, heat and biogas storages' impacts on renewable energy integration. Energy 2012;37(1):255-262.

[15] Lund H, Østergaard PA. Electric grid and heat planning scenarios with centralised and distributed sources of conventional, CHP and wind generation. Energy 2000;25(4):299-312.

[16] Østergaard PA. Transmission-grid requirements with scattered and fluctuating renewable electricity-sources. Applied Energy 2003;76(1ГÇô3):247-255.

[17] Østergaard PA. Modelling grid losses and the geographic distribution of electricity generation. Renewable Energy 2005;30(7):977-987.

[18] Østergaard PA. Regulation strategies of cogeneration of heat and power (CHP) plants and electricity transit in Denmark. Energy 2010;35(5):2194-2202.

[19] Münster M, Morthorst PE, Larsen HV, Bregnb+a k L, Werling J, Lindboe HH, et al. The role of district heating in the future Danish energy system. Energy 2012; corrected proof(0):

[20] Münster M, Meibom P. Optimization of use of waste in the future energy system. Energy 2011;36(3):1612-1622. 
[21] Ahn C, Li CT, Peng H. Optimal decentralized charging control algorithm for electrified vehicles connected to smart grid. Journal of Power Sources 2011;196(23):10369-10379.

[22] Kempton W, Tomic J. Vehicle-to-grid power implementation: From stabilizing the grid to supporting large-scale renewable energy. Journal of Power Sources 2005;144(1):280-294.

[23] Pillai JR, Heussen K, +ÿstergaard PA. Comparative analysis of hourly and dynamic power balancing models for validating future energy scenarios. Energy 2011;36(5):3233-3243.

[24] Østergaard PA. The impact on wind power integration frem geothermal absorption heat pumps and compression heat pumps. Proceedings 2012 International Conference on Clean and Green Energy, Hong Kong January 2012;

[25] Kempton W, Tomic J. Vehicle-to-grid power fundamentals: Calculating capacity and net revenue. Journal of Power Sources 2005;144(1):268-279.

[26] Kempton W, Kubo T. Electric-drive vehicles for peak power in Japan. Energy Policy 2000;28(1):9-18.

[27] Kempton W, Letendre SE. Electric vehicles as a new power source for electric utilities. Transportation Research Part D: Transport and Environment 1997;2(3):157-175.

[28] Lund $\mathrm{H}$, Kempton $\mathrm{W}$. Integration of renewable energy into the transport and electricity sectors through V2G. Energy Policy 2008;36(9):3578-3587.

[29] Tomic J, Kempton W. Using fleets of electric-drive vehicles for grid support. Journal of Power Sources 2007;168(2):459-468.

[30] W.Kempton, J.Tomic, S.Letendre, A.Brooks, T.Lipman. Vehicle-to-Grid Power: Battery, Hybrid and Fuel Cell Vehicles as Resources for Distributed Electric Power in California. 2001;1-77.

[31] Lund H, Østergaard PA, Stadler I. Towards 100\% renewable energy systems. Applied Energy 2011;88(2):419-421.

[32] Østergaard PA. Reviewing optimisation criteria for energy systems analyses of renewable energy integration. Energy 2009;34(9):1236-1245.

[33] Sanseverino ER, Di Silvestre ML, Ippolito MG, De Paola A, Lo Re G. An execution, monitoring and replanning approach for optimal energy management in microgrids. Energy 2011;36(5):3429-3436.

[34] Tsengenes G, Adamidis G. A multi-function grid connected PV system with three level NPC inverter and voltage oriented control. Solar Energy 2011;85(11):2595-2610.

[35] Mainali B, Silveira S. Financing off-grid rural electrification: Country case Nepal. Energy 2011;36(4):2194-2201.

[36] Lund H. Renewable energy strategies for sustainable development. Energy 2007;32(6):912-919.

[37] Mathiesen BV, Lund H, Karlsson K. 100\% Renewable energy systems, climate mitigation and economic growth. Applied Energy 2011;88(2):488-501.

[38] Lund H, Mathiesen BV. Energy system analysis of $100 \%$ renewable energy systems--The case of Denmark in years 2030 and 2050. Energy 2009;34(5):524531.

[39] Alberg Østergaard P, Mathiesen BV, Möller B, Lund H. A renewable energy scenario for Aalborg Municipality based on low-temperature geothermal heat, wind power and biomass. Energy 2010;35(12):4892-4901. 
[40] Østergaard PA, Lund H. A renewable energy system in Frederikshavn using low-temperature geothermal energy for district heating. Applied Energy 2011;88(2):479-487.

[41] Kwon PS, +ÿstergaard PA. Comparison of future energy scenarios for Denmark: IDA 2050, CEESA (Coherent Energy and Environmental System Analysis), and Climate Commission 2050. Energy 2012;46(1):275-282.

[42] Lund H, Andersen AN, Østergaard PA, Mathiesen BV, Connolly D. From electricity smart grids to smart energy systems - A market operation based approach and understanding. Energy 2012;42(1):96-102.

[43] Nielsen S, Sorknæs P, Østergaard PA. Electricity market auction settings in a future Danish electricity system with a high penetration of renewable energy sources ГÇô A comparison of marginal pricing and pay-as-bid. Energy 2011;36(7):4434-4444.

[44] CEPOS. Wind Energy - the case of Denmark. 2009;

[45] Sharman H. Why wind power works for Denmark. Proceedings of ICE Civil Engineering 2005;158(13663):66-72.

[46] Davey E, Ferguson A. A Plain Man's Quenstions Concerning Wind power. Optimum Population Trust 2005;5(2):

[47] Ferguson A, George. A Plain Man's Questions: Wind power in Theory and Practice. Optimum Population Trust 2012;5(2):

[48] Inhaber $\mathrm{H}$. Why wind power does not deliver the expected emissions reductions. Renewable and Sustainable Energy Reviews 2011;15(6):2557-2562.

[49] entsoe. entsoe. 2012;

[50] Energinet.dk. Download of market data. 2010;

[51] Energistyrelsen. Energistatistik 2010. 2011;

[52] Østergaard PA. Geographic aggregation and wind power output variance in Denmark. Energy 2008;33(9):1453-1460.

[53] Poul Alberg Ø. Ancillary services and the integration of substantial quantities of wind power. Applied Energy 2006;83(5):451-463.

[54] Chen Z, Blaabjerg F. Wind farm - A power source in future power systems. Renewable and Sustainable Energy Reviews 2009;13(6ГÇô7):1288-1300.

[55] Krozer Y. Cost and benefit of renewable energy in the European Union. Renewable Energy 2013;50(0):68-73.

[56] Energinet.dk. Effektiv anvendelse af vindkraftbaseret el i Danmark, samspillet mellem vind, varmepumper og elbiler (Efficient use of wind power using heat pumps and battery electric vehicles). Fredericia, Denmark: Energinet.dk (Danish TSO); 2009.

[57] Lund H, Salgi G. The role of compressed air energy storage (CAES) in future sustainable energy systems. Energy Conversion and Management 2009;50(5):1172-1179.

[58] Henrik Lund. Renewable Energy Systems. The Choice and Modeling of 100\% Renewable Solutions. Burlington, USA: Academic Press (Elsevier); 2010.

[59] Mathiesen BV, Lund H. Comparative analyses of seven technologies to facilitate the integration of fluctuating renewable energy sources. IET Renewable Power Generation 2009;3(2):190-204.

[60] Andersen AN, Lund H. New CHP partnerships offering balancing of fluctuating renewable electricity productions. Journal of Cleaner Production 2007;15(3):288-293. 
[61] Lund H. Large-scale integration of optimal combinations of PV, wind and wave power into the electricity supply. Renewable Energy 2006;31(4):503-515.

[62] Lund H, Munster E. Integrated energy systems and local energy markets. Energy Policy 2006;34(10):1152-1160.

[63] Lund H. Large-scale integration of wind power into different energy systems. Energy 2005;30(13):2402-2412.

[64] Lund H, Østergaard P, Andersen AN, Hvelplund F, Mæng H, Münster E, et al. Lokale Energimarkeder (Local Energy Markets). 2004;

[65] Danish Energy Agency. Rapport fra arbejdsgruppen om kraftvarme- og VEelektricitet (Report from the expertgroup on CHP- and RES-electricity). Copenhagen: Danish Energy Agency; 2001.

[66] Meibom P, Kiviluoma J, Barth R, Brand H, Weber C, Larsen HV. Value of electric heat boilers and heat pumps for wind power integration. Wind Energy 2007;10(4):321-337.

[67] Meibom P, Weber C, Barth R, Brand H. Operational costs induced by fluctuating wind power production in Germany and Scandinavia. IET Renewable Power Generation 2009;3(1):75-83.

[68] Ea Energianalyse. 50\% vindkraft i Danmark i 2025 - en teknisk-økonomisk analyse. (50 per cent wind power in Denmark year 2025 - Summary available in english). 2007;

[69] Mathiesen BV, Lund H, Karlsson K. IDAs Klimaplan 2050, baggrundsrapport Tekniske systemanalyser, brændselsforbrug, drivhusgasser, samfundsøkonomiske konsekvenser, erhvervspotentialer, beskæftigelseseffekter samt helbredsomkostninger (IDAs Climate Plan 2050, background report in Danish and English). 2009;

[70] Lund H, Münster E. Modelling of energy systems with a high percentage of CHP and wind power. Renewable Energy 2003;28(14):2179-2193.

[71] Lund H. Renewable Energy Systems. The Choice and Modeling of $100 \%$ Renewable Solutions. Burlington, USA: Academic Press (Elsevier); 2010.

[72] Lund $\mathrm{H}$. The implementation of renewable energy systems. Lessons learned from the Danish case. Energy 2010;35(10):4003-4009.

[73] Lund H, Munster E. Integrated transportation and energy sector CO2 emission control strategies. Transport Policy 2006;13(5):426-433.

[74] Lund H, Hvelplund F, Mathiesen BV, Meyer NI, Connolly D, Morthorst PE, et al. Coherent Energy and Environmental System Analysis. Aalborg: Department of Development and Planning, Aalborg University; 2011.

[75] Lund H, Andersen AN. Optimal designs of small CHP plants in a market with fluctuating electricity prices. Energy Conversion and Management 2005;46(6):893-904.

[76] Henrik Lund, Frede Hvelplund, Poul Østergaard, Bernd Möller, Brian Vad Mathiesen, Anders N.Andersen, et al. Danish Wind Power - Export and Cost. Aalborg, Denmark: Department of Development and Planning, Aalborg University, http://www.energyplanning.aau.dk/Publications/DanishWindPower.pdf; 2010.

[77] Pöyry. New Design for the Electricity Market. 2009;

[78] Statnett. State of the Nordic Power System Map. 2012;

[79] eurostat. Electricity - domestic consumers - half yearly prices - new methodology from 2007 onwards. 2008; 
[80] Goerten J, Ganea DC. Electricity prices for first semester of 2008. Eurostat Data in focus 2008;45

[81] eurostat. Electricity - industrial consumers - half-yearly prices - new methodology from 2007 onwards. 2008;

[82] Østergaard.P, Morthorst PE, Moesgaard R, Enevoldsen S. The impact of wind power on power spot prices in Denmark. (In Danish: Vindkraftens betydning for elprisen i Danmark). Aarhus: IBT-Wind, Aarhus University; 2006.

[83] Munksgaard J, Morthorst PE. Wind power in the Danish liberalised power market--Policy measures, price impact and investor incentives. Energy Policy 2008;36(10):3940-3947. 